\title{
Disintermediation of traditional chemical intermediary roles in the electronic business-to-business (e-b2b) exchange world.
}

\begin{abstract}
The traditional chemical distribution industry is a multi-billion dollar business and with the introduction of electronic Business-to-Business (e-B2B) exchanges to the global chemical industry there is some concern about the future roles of traditional intermediaries (TI). The objectives of this research paper are to investigate the possibility of disintermediation of roles of TI by e-B2B exchanges and to identify the value adding role of TI as perceived by chemical distributors and buyers. If these value adding roles may be the key to future survival for TI in the marketplace. International data collected from e-B2B exchanges, chemical distributors and buyers are used. Content analysis of e-B2B exchanges was conducted while survey questionnaires were used for distributors and buyers using a cross-sectional approach.The research shows that whilst the e-B2B exchanges have a role to play in the chemical supply chain management there were still sub-functions which the buyers viewed that the TI could offer to them. So the supplier-buyer relationships could be maintained between the buyers and the TI, at least for the time being, until newer business models of e-B2B exchanges begins to compete with the TI's to offer these sub-functions.The research holds valuable implications for TI in the chemical industry regarding the need for differentiation with a view building new competences to survive the encroachment of their traditional business base by e-B2B exchanges.The impact of e-B2B exchanges on TI in the chemical industry has not previously been studied in depth. This paper provides new knowledge and makes a contribution by providing evidence of evolution in the chemical distribution channels.
\end{abstract}

Keyword(s): disintermediation, e-B2B Exchanges, Chemical industry, supply chain management

\section{Introduction}

Much has been written about Electronic Commerce (EC) and Electronic Business-toBusiness (e-B2B) exchanges in relation to the roles they play and these roles seems to be numerous (e.g Smith, 2009; Bull 2010). This view was also supported by the argument that outdated distribution channels were being replaced by distributors that could add value to the customers (Hammer 2000) with traditional goods, services and information supply chains being obliterated in the process (Datta 2005). Hence, manufacturers can by-pass traditional intermediaries (TI) such as distributors, resellers, dealers and retailers by selling direct by using the internet channels (Lee, Lee \& Larsen 2003; Day and Bens, 2005). The introduction of e-B2B exchanges to the chemical industry has raised concerns about the future roles of TI for chemical 
distributions. Can e-B2B exchanges cause channel conflict and disintermediation of the TI? Are there TI roles that can be usurped by e-B2B exchanges?

This research aims to assess the possible current and future impact of e-B2B exchanges on the roles of TI in the global chemical industry, thus allowing strategic planners across that sector to better anticipate changes in distribution dynamics and buyers' preferences. The research also examined the roles that chemical distributors considered as important to the buyers in order to continue their services to the buyers and also the roles that buyers considered as important to them in retaining the services of the distributors.

\section{Literature review}

\section{Roles of Traditional Intermediaries (TI)}

All products produced by manufacturers have to be delivered in a timely manner to the correct location and to the right people (Chung 2001). TI play an important role for both the manufacturers and buyers (Balabanis, 2005; Giaglis et al. 2002). In broad terms, buyers utilise TI because they have the advantage of a single sourcing centre. The TI represents other manufacturers, conduct business on a long-term basis, make the effort to build on relationships with buyers and provide a shorter supply lines to the buyers by keeping stocks. Malone, Yates and Benjamin (1987) provide the reasons to have TI's as advocating consistency in standards, allocations of assets and reducing the costs in coordination. Issues like search costs, inadequate market feedback, risks in providing prices and contracts' fulfillment are better managed by TI as highlighted by Bailey \& Bakos (1997).

According to Whinston, Stahl and Choi (1997), the TI helps to facilitate transactions between buyers and manufacturers through providing value-added service such as product quality assurances, product warranties and information, logistics support and aggregation. Aggregation is where the buyers and manufacturers are brought together under one roof to provide a one-stop shopping (Kaplan \& Sawhney 2000). The TI enhances their roles by offering an effective supply chain to meet the customers' requirements at a competitive cost (Ovenby and Min, 2002; Fung et.al, 2007). There is no literature that merges all the previous research into a single coherent study on the total roles of the TI. This study compiles all the market functions and sub-functions roles of the TI into a coherent framework for research purposes.

\section{Channel Conflict and Disintermediation by e-B2B Exchanges}

E-B2B exchanges have substantially different characteristics between the various eB2B exchanges in terms of their industry and product focus (Christiaanse et al., 2001) the type of relationship and power asymmetries between buyers and suppliers, and the type of product sourcing (Pavlou \& El Sawy 2002). Kaplan and Sawhney (2000, p. 97) observed that “...the appeal of doing business on the web is clear. By bringing together huge numbers of buyers and sellers and by automating transactions, web markets expand the choices available to buyers, give sellers access to new customers, and reduce transactions costs for all the players".

The e-B2B exchanges can be classified by functionality in terms of what businesses buy, and how they buy and also by their ownership. Chart 1 shows the eB2B exchanges classified by its ownership model as proposed by Hoffman, Keedy and Roberts (2002). 


\section{Chart 1: e-B2B Exchanges Classification by Ownership Structures}

Independent Exchange

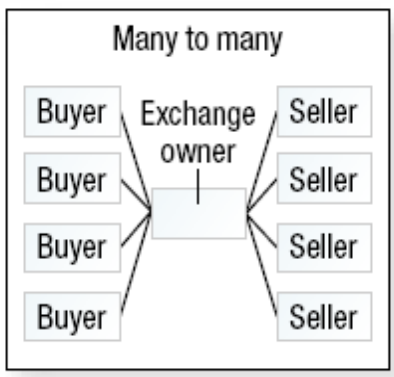

Consortium-led Exchange

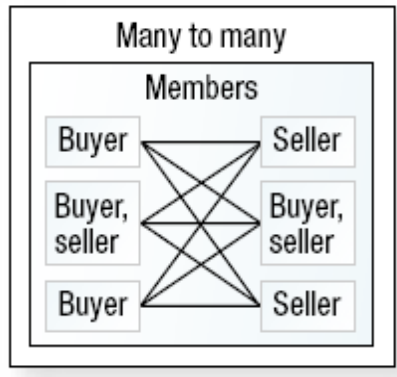

Private Exchange

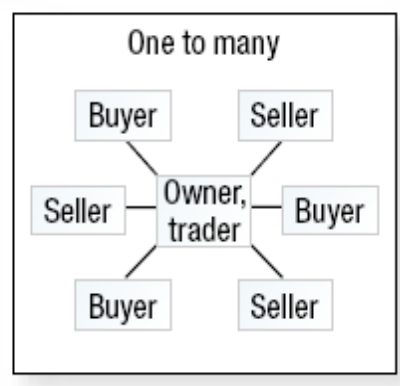

Source: Hoffman, Keedy \& Roberts (2002, p. 99)

Through the introduction of e-B2B exchanges, chemical manufacturers now have an alternative distribution channel. Ruijter (2004) described e-B2B exchange as an electronic marketplace (Bakos, 1991) where buyers and sellers can meet to negotiate for products they wanted to buy and sell at competitive prices through internet facilities (Bakos, 1997; 1998). This definition of e-B2B exchanges is adopted in this study. Forrester Research (Kafka, Temkin, Doyle, Brown \& Martin 2000) predicted that only about 180 e-B2B exchanges would survive in 2003 out of the 1,000-plus exchanges that were in existence in 2000. However, this was not accurate. eMarket Service (2004, cited in e-Business market w@tch, 2004) estimated there were still about 1,000 e-B2B exchanges in the chemical and related industries alone. The breakdown is shown in Table 1. North America alone has 378 e-B2B exchanges in the chemical and related industries. eMarket Service estimated there were only 34 e-B2B exchanges in the chemical industry as shown in Table 1. If Plastic and Rubber industries are included as part of the chemical industry then there were a total of $57 \mathrm{e}$ $\mathrm{B} 2 \mathrm{~B}$ exchanges in the chemical industry. This research is confined to e-B2B exchanges involved in the chemical industry.

Table 1: Estimated Number of e-B2B Exchanges (June 2004)

\begin{tabular}{|l|r|r|r|}
\hline & World & Europe & North America \\
\hline Total & 948 & 489 & 378 \\
\hline Chemical Industry & 34 & 15 & 15 \\
\hline Plastics and Rubber & 23 & 10 & 10 \\
\hline Medical and Pharmaceuticals & 44 & 21 & 24 \\
\hline Paper and Pulp & 11 & 5 & 3 \\
\hline Energy and Fuels & 41 & 21 & 25 \\
\hline
\end{tabular}

Note: The regional information denotes activity (e.g. sales offices) within the respective region, not necessarily the headquarters.

Source: eMarket Service (2004, cited in e-Business market w@tch 2004)

\section{Disintermediation}


Wigand (1997) defines disintermediation as where the market intermediaries are either displaced or eliminated and manufacturers and buyers are trading directly with each other without the presence of agents. So in the case of disintermediation by eB2B exchanges, manufacturers can bypass TI and supply their products through eB2B exchanges. Sarkar, Butler and Steinfield (1996) argued that prices would decrease owing to the disappearance of margins calculated by the TI when buyers go online to transact directly with online suppliers. This is inferring that suppliers can offer the services previously supplied by TI much more efficiently. This may not be true and the statement may be over-simplified. Regardless, Kuttner (1998, cited in Brousseau 1999, p. 5) wrote that "the internet is a nearly perfect market because information is instantaneous and buyers can compare the offerings of sellers worldwide and the result is fierce price competition, dwindling product differentiation and vanishing brand loyalty".

Since the 1990's disintermediation were been mentioned in the context of e-B2B exchanges where established TI are removed in favour of decreased costs to the buyers and sellers (Mills \& Camek 2004). Buyers are aware of the prices directly from manufacturers due to the highly transparent market structure and this can lead to disintermediation of the TI. Aggregation of buyers and sellers are the key benefits of e-B2B exchanges. It can be argued that e-B2B exchanges are well suited to perform the task of aggregation of buyers and sellers and users could benefit from the lower cost of transactions (Fingar, Kumar \& Sharma 2000). Formisano (2004) stated that if your competitors are selling online, there is no way to eliminate the problem of channel conflict. Rosenbloom (2007, p. 4) commented that “...unquestionably the greatest force to impact market channel strategy in at least the last half century has been internet-based EC. The availability of on-line channel option means that now virtually every firm, whether large or small, must include the internet as a channel for reaching its customers". Is there any truth to these statements? If they are true, then this will be the end for the TI in the e-B2B exchange world and all manufacturers will bypass the TI and go directly to the buyers. Can B2B exchanges really be as efficient as it claimed to be and cause total disintermediation of the TI?

Forrester Research (2000, cited in Cap Gemini Ernst \& Young and the University of Tennessee 2000) predicted that as much as US\$2.7 trillion in sales would be transacted by 2004 through e-B2B exchanges for the industries mentioned in Chart 2 and this represents only $10 \%$ of the entire e-B2B market. Chemical products are used in all the industries mentioned in Chart 2 except for warehousing and industrial supplies and it was estimated that as much as $40 \%$ of the sales value (about US\$100 billion) would be from chemicals by year 2004.

However, the Banc of America Securities (ND, cited in Thayer 2000) has a more conservative prediction of the global EC market of about US\$300 billion in 2003 and the U.S. chemical EC sales would be about US\$75 billion as shown in Chart 3. They further predicted that the global EC market will grow to US\$450 billion by year 2005 with $24 \%$ attributed to chemical market share amounting to about US $\$ 120$ billion. How true are these projections now that the years have passed? The U.S. Census Bureau (www.census.gov) (USCB) in their May 2006 report stated that EC sales in the U.S. for the chemical manufacturing, plastic and rubber sectors amounted to US\$135 billion out of the total shipment value of US\$709 billion for 2004. This was an increase from the year 2003 figure of EC sales of US\$112 billion out of the total shipment value of US\$664 billion. So when compared with the USCB statistics, the Banc of America Securities and Forrester Research projections were grossly under-estimated and in reality the actual EC sales in the U.S. were much 
higher than estimated. So in summary these statistics provided the evidence that EC sales for chemical products are growing in the marketplace.

Chart 2: e-B2B Business will Grow to US\$2.7 trillion by Year 2004
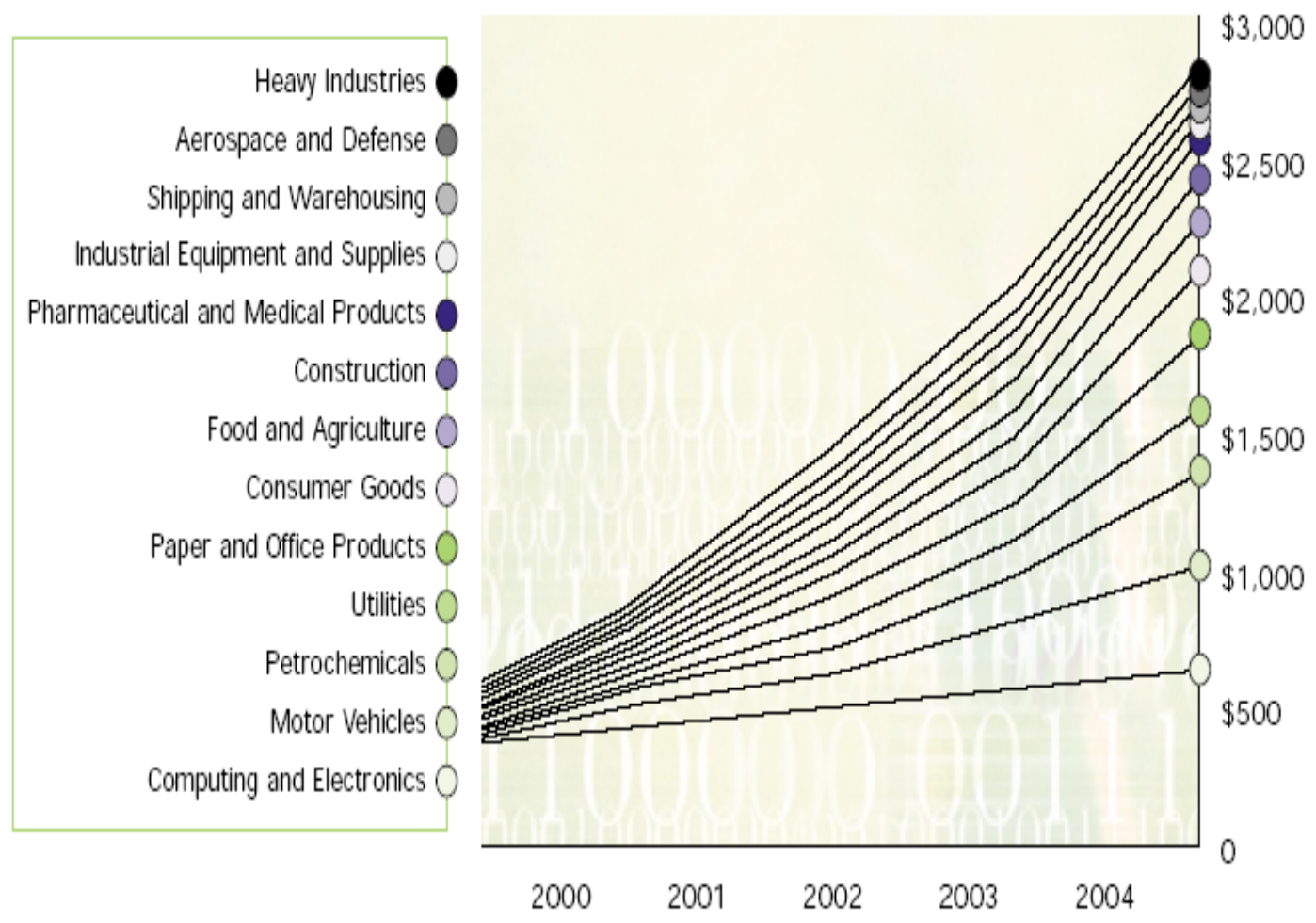

Source: Forrester Research

Source: Forrester Research (2000, cited in Cap Gemini Ernst \& Young and the University of Tennessee 2000)

Chart 3: Prediction of US Chemical e-Commerce Sales (2003)

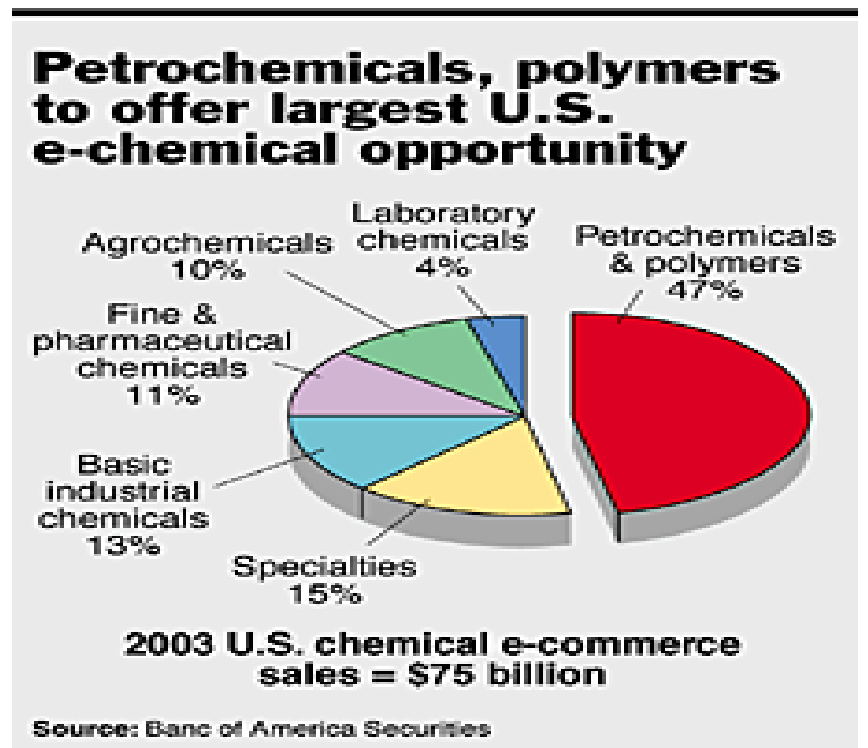

Source: Banc of America Securities (ND, cited in Thayer 2000) 
Purchasing Magazine online (www.purchasing.com) published the top 100 chemical distributors 2007 in North America and their sales averaged to be US\$215 million. The top 100 North American chemical distributors have a combined turnover of US\$ 21.5 billion. The top five North American chemical distribution companies all have sales in the billions of US dollars (Brentag Americas, 2008). The sales turnover figures of the prominent e-B2B chemical exchanges also provided further insight on the growth of EC sales in the chemical industry. Chemconnect and Elemica, both prominent e-B2B exchanges in the chemical industry, recorded sales turnover of billions of US dollars in 2002 and 2007 respectively. All these companies are international players in the traditional chemical distribution business. This provided some evidence that the TI still have a role to play presently in the chemical distribution business. No evidence was found that made any direct reference to the areas where e-B2B exchanges sales specifically came from. The sales from e-B2B exchanges have to be diverted from somewhere and there is likelihood that some of the eB2B exchanges sales was taken away from the TI through disintermediation.

\section{Research questions}

From the literature review, the research problem can be presented as follows.

Within the context of the chemical supply chain, there is lack of clarity about the role of e-B2B exchanges. Currently both e-B2B exchanges and the distributors were operating side-by-side as evidenced by the information above. So if e-B2B exchanges were so efficient, as mentioned previously, then why were they not taking over all the business from the distributors? Or was it just a matter of time before they do? It is important to assess the perceptions of the buyers to determine which market functions they perceived as important in the current distribution channel. If distributors gain a good appreciation of buyers' perceptions in terms of what is seen as value adding services, then distributors may be in a better position to formulate strategic marketing plans to retain business from the buyers.

For the purposes of this research, it was necessary to observe the effects of the combinations of the independent variables in addition to the effect of each one individually. Figure 1 shows the independent and dependent variables for this research framework for evaluating the importance of each of the independent variables to the buyers, how much they appreciate the value-adding element and finally whether this was enough to retain the services of the distributors. 
Figure 1: Independent and Dependent Variables Framework

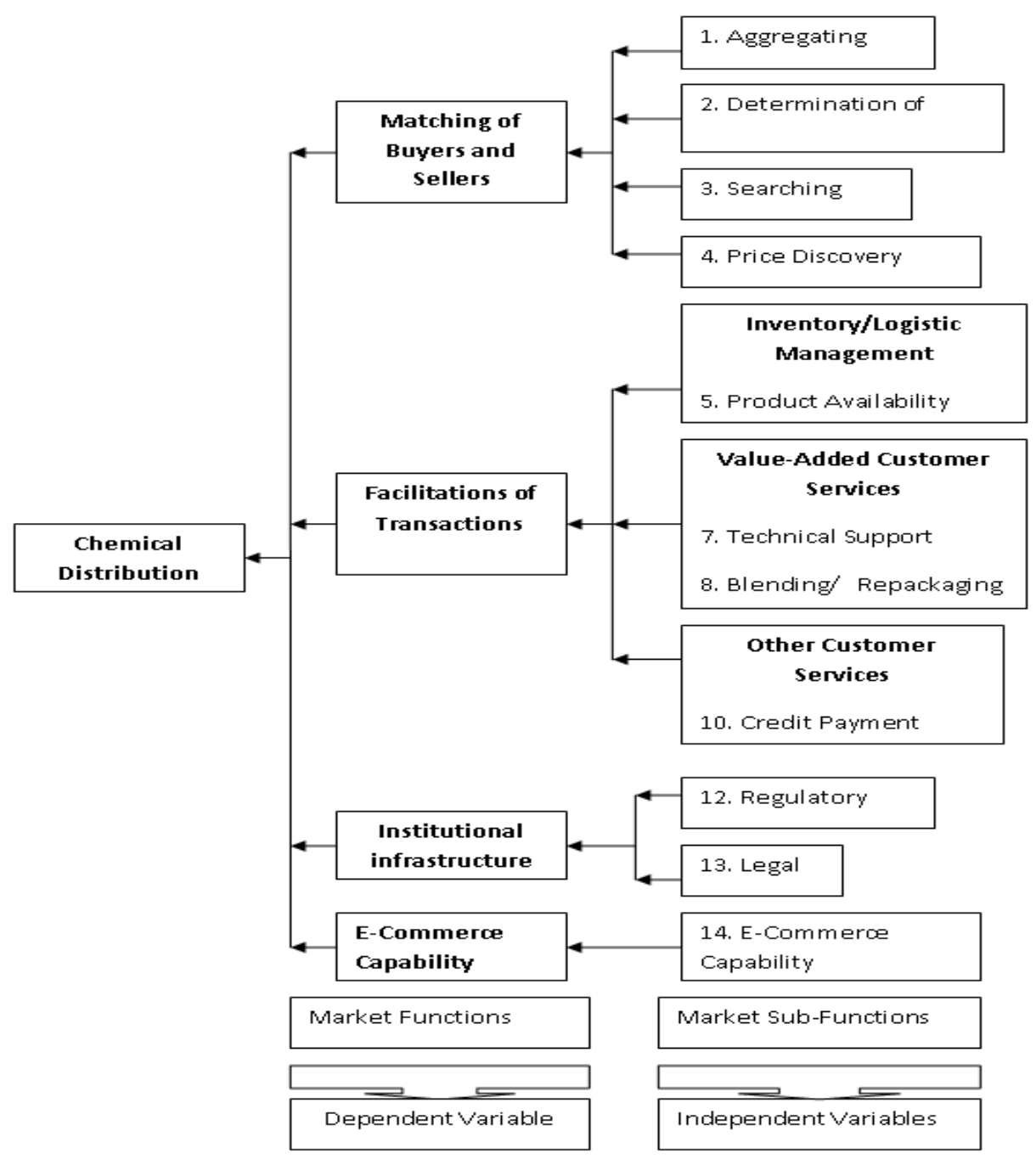

It is not known whether e-B2B exchanges cause any degree of disintermediation of the roles of TI. If they do cause disintermediation, what are the functions that they usurp from from TI? From the chemical distributors' perspective, it is worth exploring their perception of the usefulness of TI and e-B2B exchanges. For this research the following questions were researched:

1. Were e-B2B exchanges able to substitute the roles of the TI for the market functions identified?

2. What services were chemical distributors offering that attracts the buyers to continue to buy from chemical distributors rather than through e-B2B exchanges?

3. What are the services that distributors could possibly offer chemical buyers so that buyers retain their services rather so as to prevent them from using e-B2B exchanges?

\section{Research Methodology}

Research Paradigm

This research was grounded in the interpretivist paradigm with inductive reasoning. Interpretivist research relies upon the "participants' view of the situation being studied" (Creswell 2003, p.8). As this research did not begin with a theory, throughout the research process the phenomena and patterns were inductively generated and the relationships were formulated to develop a theory (Creswell 2003). 
The participants' views (distributors and buyers) were surveyed and from the findings, the appropriate conclusions as to whether e-B2B exchanges might have caused the disintermediation of the TIs' roles were drawn. Quantitative statistical data analysis methods were used to better understand the patterns and relationships from the data collected on the market sub-functions of the TIs' roles.

Research Strategy

Yin (1994) proposes five research strategies for researchers to choose, those being, experiment, survey, archival analysis, history and case study. The relevant situations for different research strategies are as shown in Table 2.

Table 2: Relevant Situations for Different Research Strategies

\begin{tabular}{|l|l|c|c|}
\hline \multicolumn{1}{|c|}{ Strategy } & \multicolumn{1}{|c|}{$\begin{array}{c}\text { Form of research } \\
\text { question }\end{array}$} & $\begin{array}{c}\text { Requires control } \\
\text { over behavioral } \\
\text { events }\end{array}$ & $\begin{array}{c}\text { Focuses on } \\
\text { contemporary } \\
\text { events }\end{array}$ \\
\hline Experiment & How, why & YES & YES \\
\hline Survey & $\begin{array}{l}\text { Who, what, where, how } \\
\text { many, how much }\end{array}$ & NO & YES \\
\hline $\begin{array}{l}\text { Archival } \\
\text { analysis }\end{array}$ & $\begin{array}{l}\text { Who, what, where, how } \\
\text { many, how much }\end{array}$ & NO & YES/NO \\
\hline History & How, why & NO & NO \\
\hline Case Study & How, why & NO & YES \\
\hline
\end{tabular}

Source: Yin (1994, p. 6)

Survey and archival analysis strategies were considered the most appropriate for further consideration. For these two strategies the researcher asks the "who", "what", "where", "how many" and "how much" questions. In archival analysis, the researchers identify the relevant source or sources, collect the necessary information and record the information. The archives are viewed as an object whose goal is preservation of information, documents and records (Gilliland \& McKemmish 2004).

Scandura and Williams (2000) state that archival studies use secondary data which are data collected by a person, agency or organisation other than the researcher. This research will not rely on secondary data for its input although information will be gleaned from the internet sites and subsequently assessed and categorized. For research on disintermediation of TI, archival research would not be appropriate as the information sought is not readily available in archives as it is contemporary.Surveys are used to gain a "snapshot of a section of the society at a particular point in time with the intention being to generalize from that group to the population as a whole” (McQueen \& Knussen 2002, p. 36). A survey can be conducted using the different techniques (Baker 2008) including:

1. Structured and in-depth interviews;

2. Structured, semi-structured or systematic observation;

3. Content analysis; and

4. Questionnaires.

There were three main sources of information for this investigation, i.e. e-B2B exchanges, chemical distributors and buyers. The data collected from these three sources allows the researcher to draw better conclusions as to whether the phenomenon of disintermediation was taking place or otherwise. For this research a mix of two techniques i.e. content analysis of e-B2B exchanges and survey questionnaires for the distributors as well as for buyers was chosen. Content analysis 
of e-B2B exchanges may at first impression be interpreted as part of archival studies. As mentioned above, archival study uses secondary data which is not the case here. For secondary data the researcher does not have to specially collect it as the data exists already (Cavana, Delahaye \& Sekaran 2001). No doubt for content analysis of e-B2B exchanges the information already exists but the information has to be extracted, analysed and interpreted just like primary data. In this research the data collected are from the actual location of events and these are primary data (Hair et al. 2003a). So content analysis in this research should not be taken as archival research.

\section{Design and Methodology}

The approach to this study was exploratory using a descriptive research design with a quantitative data collection approach. It was undertaken in order to describe and ascertain the characteristics of the market sub-functions of the TI in today's world of electronic commerce as accurately as possible with all other factors such as sampling constraints held constant. Quantitative statistical data analysis was used to generate information to determine the relationships between the market functions and also the purchasing trend of buyers. The analysis of the data identified the market functions that distributors and buyers perceived as important to them to continue with the suppliers-buyers relationships. Data were collected using the internet website online survey as this offered the most cost effective, fast access to questionnaires as well as, international access to respondents, and an easy reply method.

Content analysis was used for data collected on e-B2B exchanges websites and to evaluate the functionalities of the e-B2B exchanges. This study also intended to identify the presence of specific functionalities of the e-B2B exchange websites and where it might be possible to substitute the roles of TI's. The content analysis approach was the best method for identifying the presence of such data (Berg 2001). Krippendorf (2004, p.18) defines content analysis as "a research technique for making replicable and valid inference from text or other meaningful matter to the context of their use”. Content analysis is unobtrusive, can handle unstructured matter and can cope with large volume of data (Krippendorf (2004) and so it is well suited to analyse e-B2B exchanges websites. Using content analysis to investigate the worldwide-web is an established research technique (McMillan 2000) and researchers have used content analysis to investigate websites before (Ghose \& Dou 1998; Huizingh 2000; and Perry \& Bodkin 2000).

The data was collected from three sources: websites of e-B2B exchanges and from chemical distributors and buyers using self-completion questionnaires.The triangulation approach used in this research ensures the corroboration of data as well as providing convergent validation of the data from the three sources.

For the purposes of this research, the cross-sectional approach was utilized. The cross-sectional approach involves collecting data over a short period of a few days or a few months, once only to meet the research objectives. If disintermediation was happening in the marketplace, it would be evident even if the information was collected using the cross-sectional approach as the phenomenon is a continuous process and was not likely to occur in a cyclical manner. Cross-sectional analysis of websites allows researchers to compare the various types of electronic transactions and the effectiveness of the different websites at a specific point in time and reliable benchmark data can be obtained from a comparative analysis (Perry \& Bodkin 2000). So the cross-sectional approach was thus deemed to be sufficient for the purpose of this research. 


\section{Sampling Population and Size}

Convenience sampling, a non-probability sampling technique, was chosen. The top 50 global chemical producers were researched first for their e-B2B exchanges. They fell under the classification of private exchanges because the exchanges were owned by the companies themselves. The search was further extended to web search using key words like "e-B2B exchanges”, “e-business”, “chemical exchanges” and "chemical portals" to cover the independently owned and consortium-led type e-B2B exchanges. Only e-B2B exchanges dedicated to the chemical trade were considered in this research.

The sampling population for the survey of distributors was drawn from the following categories:

1. North American Chemical Distributor Association (www.nacd.org);

2. European Chemical Distributors Association (www.fecc.org);

3. British Chemical Distributor and Trade Association (www.chemical.org.uk);

4. Canadian Association of Chemical Distributors (www.cacd.ca);

5. Purchasing Magazine Online (www.purchasing.com) top 100 chemical distributors 2006 listing (North American distributors);

6. Chemical distributors from web search and trade directories; and

The sampling population for the survey of buyers was drawn from the following categories:

1. Purchasing Magazine Online (www.purchasing.com) list of chemical buyers;

2. Purchasing and supply chain management institutes, associations and trade directories;

3. Chemical buyers from web search and trade directories; and

4. External parties (who had list of buyers) whom the researcher has access to.

Questionnaire Design

For distributors and buyers the questionnaires were carefully designed to ensure that responses obtained will be most representative of the true perceptions of the respondents. The questions selected are of a closed type format where the respondents have to make a choice. This type of question design allows the respondents to decide readily and also allows the researcher to code the information easily (Hair et al. 2003a). There are two main parts to the questionnaires for the distributors and buyers. The first part is on the organisation's demographics such as the number of employees, annual sales/purchasing volume, whether they have EC capability and questions on the purchasing trends for e-B2B exchanges. The second part is on the market subfunctions.Internet website online survey was carried out which entails a questionnaire being posted on a website and the prospective respondents have to read and answer the questions by themselves (Schmidt \& Hollensen 2006). A standardised email message was sent to prospective respondents with an information letter and a hyperlink to a dedicated web page where the survey questionnaires were posted. After completing the survey, the respondent returned it to the researchers electronically by clicking on a navigation button provided in the webpage. With internet technology becoming available to more people and the ease of their usage internet website survey method is becoming very popular for data collection (Malhotra \& Birks 2007). Figure 2 shows the independent and dependent variables and where data was collected from the sampling populations of e-B2B exchanges, distributors and buyers. 
Figure 2: Independent and Dependent Variables for Sampling Population

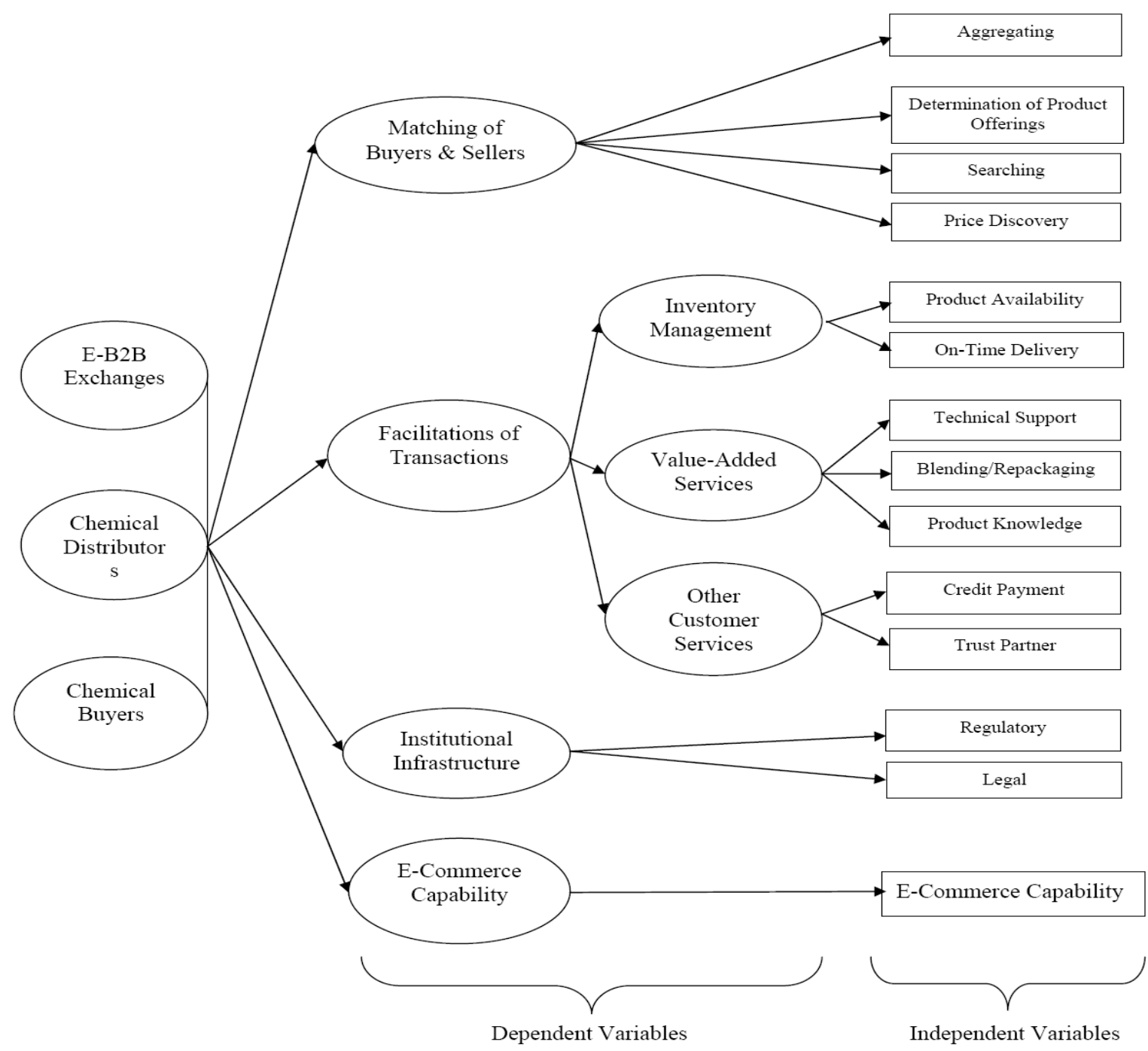

\section{Results}

\section{Content Analysis of e-B2B Exchanges}

One of the main sources of information for identifying the e-B2B exchanges was the global top 50 chemical companies list (2006). A total of 52 e-B2B exchanges participating in the chemical industry were identified.Table 3 shows the results of the content analysis of e-B2B exchanges on the roles of the TI that might be substituted by e-B2B exchanges. 
Table 3: Roles of the TI that Might be Substituted by e-B2B Exchanges

\begin{tabular}{|c|c|c|c|}
\hline $\begin{array}{l}\text { Market Functions/ } \\
\text { Sub-Functions }\end{array}$ & $\begin{array}{c}\text { Independent e- } \\
\text { B2B exchanges } \\
\text { Total }=29\end{array}$ & $\begin{array}{c}\text { Private e- } \\
\text { B2B } \\
\text { exchanges } \\
\text { Total=21 }\end{array}$ & $\begin{array}{c}\text { Consortium- } \\
\text { Led e-B2B } \\
\text { exchanges } \\
\text { Total=2 }\end{array}$ \\
\hline $\begin{array}{l}\text { Matching of Buyers and } \\
\text { Sellers } \\
\text { 1. Aggregating } \\
\text { 2. Determination of } \\
\text { Product Offerings } \\
\text { 3. Searching } \\
\text { 4. Price Discovery }\end{array}$ & 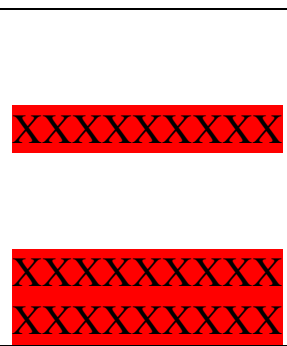 & & $\begin{array}{l}\text { \#\#\#\#\#\#\#\#\#\#\# } \\
\text { \#\#\#\#\#\#\#\#\#\#\# } \\
\text { \#\#\#\#\#\#\#\#\#\#\#\# }\end{array}$ \\
\hline $\begin{array}{l}\text { Facilitations of } \\
\text { Transactions- } \\
\text { Inventory/Logistic } \\
\text { Management } \\
\text { 5. Product Availability } \\
\text { 6. On-Time Delivery }\end{array}$ & & $\begin{array}{l}\text { KXXXXXXX } \\
\text { KXXXXXXX }\end{array}$ & $\begin{array}{l}\text { \#\#\#\#\#\#\#\#\#\#\#\# } \\
\text { \#\#\#\#\#\#\#\#\#\#\# }\end{array}$ \\
\hline $\begin{array}{l}\text { Facilitations of } \\
\text { Transactions-Value- } \\
\text { Added Customer Services } \\
\text { 7. Technical Support } \\
\text { 8. Blending/Repackaging } \\
\text { 9. Product Knowledge }\end{array}$ & & $\begin{array}{l}\text { XXXXXXXX } \\
\text { KXXXXXXX }\end{array}$ & $\begin{array}{l}\text { \#\#\#\#\#\#\#\#\#\#\# } \\
\text { \#\#\#\#\#\#\#\#\#\#\# }\end{array}$ \\
\hline $\begin{array}{l}\text { Facilitations of } \\
\text { Transactions-Other } \\
\text { Customer Services } \\
\text { 10. Credit Payment } \\
\text { 11. Trust Partner }\end{array}$ & & $\begin{array}{l}\text { KXXXXXXX } \\
\text { كXXXXXXX }\end{array}$ & $\begin{array}{l}\text { \#\#\#\#\#\#\#\#\#\#\#\#\# } \\
\text { XXXXXXXXX }\end{array}$ \\
\hline $\begin{array}{l}\text { Institutional } \\
\text { Infrastructure } \\
\text { 12. Regulatory } \\
\text { 13. Legal }\end{array}$ & & & \\
\hline
\end{tabular}

Note: e-B2B that might be able to substitute the roles of the TI for the sub-functions concerned:

\#\#\#\#\#\#\# 50\% and above of e-B2B exchanges

XXXXX 75\% and above of e-B2B exchanges

Source: From the content analysis of e-B2B exchanges

From the content analysis of the e-B2B exchanges the following conclusions were drawn:

1. For independent type e-B2B exchanges, all the 29 exchanges appear to be able to substitute the role of the TI for the function of "Matching of Buyers and Sellers" except for the sub-function of "Determination of Product Offerings" where they are not able to;

2. For private type e-B2B exchanges, all the 21 exchanges appear to be able to substitute the role of the TI for the function of "Facilitations of Transactions" except for the sub-function of "Blending/Repackaging"; and

3. For consortium-led type e-B2B exchanges, both the exchanges seem to be able to substitute the role of the TI for the sub-function of "Trust Partner". The exchanges 
would appear on the face of it to be able to substitute the roles of the TI, though on a lesser significance level, for the sub-functions of "Aggregation", "Searching", "Price Discovery”, "Product Availability”, “On-Time Delivery”, “Technical Support”, "Product Knowledge" and "Credit Payment". However as a caution, since only 2 eB2B exchanges were found under this category, these observations will have to be qualified and cannot be generalised throughout the chemical industry.

Quantitative Analysis-Survey Research

Table 4 shows the obtained sample sizes and the response rates.

Table 4: Obtained Sample Sizes and Response Rates

\begin{tabular}{|l|c|c|}
\hline & $\begin{array}{c}\text { Chemical } \\
\text { Distributors }\end{array}$ & $\begin{array}{c}\text { Chemical } \\
\text { Buyers }\end{array}$ \\
\hline a. Emails sent out & 749 & 1,050 \\
\hline $\begin{array}{l}\text { b. Emails returned as “undeliverable” } \\
\text { (b/a*100) }\end{array}$ & $81(11 \%)$ & $174(17 \%)$ \\
\hline c. Responses received & 72 & 52 \\
\hline d. Raw Response Rate (c/a)*100 & $10 \%$ & $5 \%$ \\
\hline e. Adjusted Response Rate c/(a-b)*100 & $11 \%$ & $6 \%$ \\
\hline f. Number of unusable responses & 4 & 1 \\
\hline g. Total number of usable responses & 68 & 51 \\
\hline
\end{tabular}

Source: Survey conducted for this research during the period April-May 2008

The lower response rates could be due to a number of reasons:

1. Email recipients are reluctant to open email from an unknown sender

2. Over-surveying of internet users

3. Perceived decreased level of privacy and anonymity

4. No reward in replying to the survey

5. Spam or junk email

Tuten (1997, cited in Manfreda et al. 2008) and Jones and Pitt (1999, cited in Manfreda et al. 2008) suggested that email invitations are more likely to be perceived as spam. The issue of the lowering of response rates due to the increase of junk email was also raised by many other researchers (Parker 1992; Schaefer \& Dillman 1998; Tse 1998; Dillman 2000; Sills \& Song 2002; Evans \& Mathur 2005). Griffis, Goldsby and Cooper (2003, p. 237) wrote that the decline in response rate is "prevalent in logistics research, where achieving the traditional benchmark of $20 \%$ usable responses seems less common today than ever before". Research published in the Journal of Business Logistics (JBL) (www.cscmp.org) had achieved response rates from as low as $4.32 \%$ during the period 1997 through 2001. Griffis et al. (2003) also commented that the Council of Logistic Management (CLM) too had considerable difficulty in generating sufficient response rate for their survey. The obtained adjusted response rates of $11 \%$ and $6 \%$ in this research were within the range of $4.0 \%$ and 32 $\%$ as reported in the JBL (cited in Griffis et al. 2003).

\section{Statistical Analysis of Market Sub-Functions}

The Cronbach's Alpha Coefficient for the overall scale for buyers and distributors is 0.748 and 0.723 respectively. Yang et al. (2005) suggested a Cronbach's Alpha Coefficient of 0.7 or higher was needed for the scale to be considered as reliable. Using this guideline the scale was deemed reliable and under the Hair et al. (2003b) guideline this is in the "good" range. 
The result of the one sample t-test for both the chemical buyers and distributors is as shown in Figure 3.

Figure 3: One Sample t-Test results for Chemical Buyers and Distributors (Likert Scale 1 to 5, Test Value $=3$ )

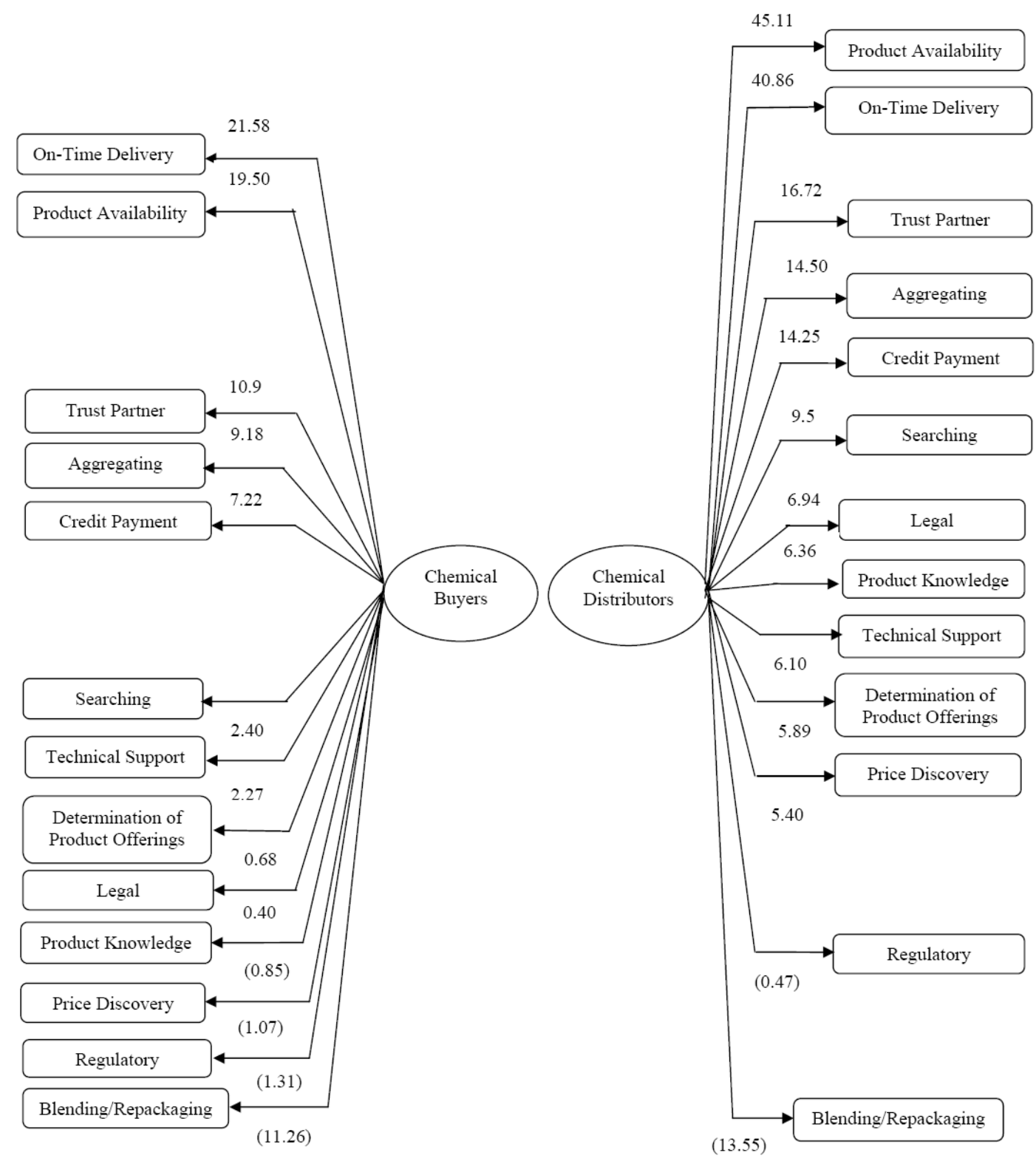

From Figure 3 above it could be seen that for the market sub-functions "OnTime Delivery”, "Product Availability”, “Trust Partner”, “Aggregating” and "Credit Payment" they have very significant positive t-Test values for both the chemical buyers and the distributors. This indicated that these are the sub-functions which the buyers and distributors viewed as very important for them. 
For the chemical buyers the sub-functions of "Searching" and "Technical Support" have only slightly positive t-Test values and hence were perceived as only being slightly more than somewhat important to buyers. For the sub-functions of "Determination of Products Offerings" and "Legal" the t-Test value is only marginally positive indicating that they are average scores only. For the market subfunctions of "Products Knowledge", "Price Discovery" and "Regulatory" and "Blending/Repackaging" they are have negative t-Test value thus indicating that they are all below average score.

However for chemical distributors the t-Test values obtained for the market sub-functions of "Searching”, "Legal”, "Products Knowledge”, "Technical Support”, "Determination of Products Offerings" and "Price Discovery" all still showed quite significant positive t-Test values. Only the market sub-functions of "Regulatory" and "Blending/Repackaging" showed negative t-Test value.

\section{Independent Two Samples t-Test}

The independent two samples t-test can be used to assess the relative difference in preferences between individual sub-functions for both the buyers and distributors. The independent group t-test is suitable for large samples where $\mathrm{N}>30$ (Triola 1998). The sample sizes for the distributors and buyers are 68 and 51 respectively which is greater than the guideline for large samples.

The independent two samples t-test was performed between the groups of buyers and distributors and the summary results are shown in Figure 4 below.There are significant differences in the group means between the distributors and buyers for the market sub-functions of "Determination of Product Offerings", "Searching", "Price Discovery", "Product Availability", "On-Time Delivery", "Product Knowledge" and "Legal" indicating significant differences in the preferences between the buyers and distributors for those sub-functions.All the t-test values obtained are in the negatives indicating that the buyers perceived level of importance of all the sub-functions were lower than the distributors.

From Figure 4 below it could be seen that for both chemical buyers and distributors the market sub-functions of "On-Time Delivery", "Product Availability”, "Trust Partner", "Aggregating” and "Credit Payment" all have very significant positive mean scores differences as compared to the test value. This indicated that these are the sub-functions which the buyers and distributors viewed as important and very important for them.

Fot the chemical buyers the five market sub-functions of "Determination of Products Offerings", "Legal”, "Products Knowledge”, "Price Discovery" and "Regulatory" do not have significant mean scores differences compared to the test value. This indicated that all these sub-functions were only somewhat important to the buyers. 
Figure 4: Independent Two Sample t-Test Results with the Mean Values (Likert Scale 1 to 5, Test Value $=3$ )

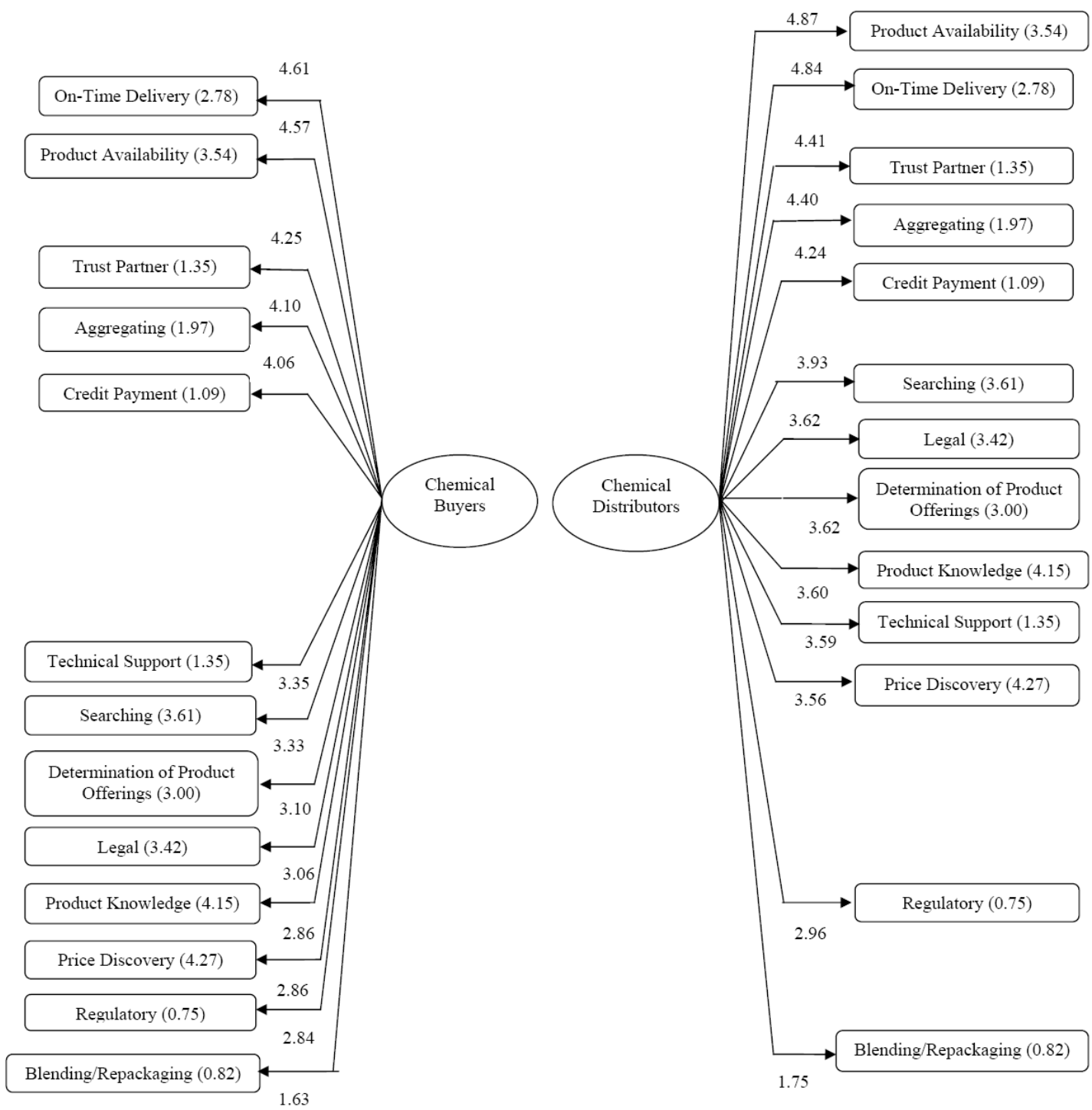

Note: Figuress in brackets above are negative t-Test values obtained from analysis of survey data

From Figure 4 above for Chemical Distrbutors it could be seen that the market sub-functions "On-Time Delivery”, "Product Availability”, “Trust Partner", "Aggregating" and "Credit Payment" have very significant positive mean scores differences compared to the test value. This indicated that these are the sub-functions which the distributors viewed as important and very important for them. The five sub-functions of "Searching", "Legal", "Determination of Products Offerings", "Products Knowledge", "Technical Support" and "Price Discovery" all showed above the average scores. This indicated that all these sub-functions were important to the distributors. The sub-function "Blending/Repackaging” has a very low mean score as compared to the test value. 


\section{Spearman Rank-Order Analysis}

The Spearman Rank-Order Analysis was performed to determine whether overall there was any agreement on the relative order of importance of the sub-functions between the distributors and buyers. The Spearman Correlation Coefficient between means is 0.934 indicated a very high degree of agreement on the overall preferences of the distributors and buyers for the sub-functions.

\section{Discussion}

Any agreement found on the perceived level of importance of the market subfunctions between the chemical distributors and buyers reinforces their supplier-buyer relationships and thus enhances their continuing roles as suppliers and buyers. From the one sample t-tests performed the perception of the level of importance of the subfunctions by both the distributors and buyers could be observed and these are summarised in Table 5.

Table 5: Buyers' and Distributors' Perception of Level of Importance on the Market Sub-Functions

\begin{tabular}{|c|c|c|}
\hline $\begin{array}{c}\text { Level of } \\
\text { Importance }\end{array}$ & $\begin{array}{l}\text { Buyers' Perception for these } \\
\text { Market Sub-Functions }\end{array}$ & $\begin{array}{c}\text { Distributors' Perception } \\
\text { for these } \\
\text { Market Sub-Functions }\end{array}$ \\
\hline Very Important & $\begin{array}{l}\text { On-Time Delivery; } \\
\text { Product Availability; } \\
\text { Trust Partner; } \\
\text { Aggregating; } \\
\text { Credit Payment; }\end{array}$ & $\begin{array}{l}\text { Product Availability; } \\
\text { On-Time Delivery; } \\
\text { Trust Partner; } \\
\text { Aggregating; } \\
\text { Credit Payment; } \\
\text { Searching; } \\
\text { Legal; } \\
\text { Product Knowledge; } \\
\text { Technical Support; } \\
\text { Determination of Product } \\
\text { Offerings; } \\
\text { Price Discovery; }\end{array}$ \\
\hline Important & $\begin{array}{l}\text { Searching; } \\
\text { Technical Support; }\end{array}$ & \\
\hline $\begin{array}{l}\text { Somewhat } \\
\text { Important }\end{array}$ & $\begin{array}{l}\text { Determination of Product } \\
\text { Offerings; } \\
\text { Legal; } \\
\text { Product Knowledge; } \\
\text { Price Discovery; } \\
\text { Regulatory; }\end{array}$ & Regulatory \\
\hline $\begin{array}{l}\text { Not at all } \\
\text { Important }\end{array}$ & Blending/Repackaging; & Blending/Repackaging \\
\hline
\end{tabular}

Source: Developed for this research

There were agreement by both the buyers and distributors regarding their perception of the level of importance of the sub-functions at the extreme ends of the scales. Both the buyers and distributors perceived the sub-functions of "On-Time Delivery", "Product Availability", "Trust Partner", "Aggregating” and "Credit 
Payment" as very important to them. Both groups also agreed that the sub-function of "Blending/Repackaging" was not at all important to them and "Regulatory" as somewhat important to them. The Spearman Correlation Coefficient between ranks indicated that there were a very high degree of agreement on the overall preferences of the distributors and buyers for the sub-functions.

There were strong agreement on the specific market sub-functions that are perceived to be very important to both the chemical distributors and buyers for them to continue their supplier-buyer relationships in the marketplace. The five subfunctions are "On-Time Delivery”, "Product Availability”, “Trust Partner", "Aggregating" and "Credit Payment". In addition to these five sub-functions, the buyers also perceived two more sub-functions which were just important to them but which the distributors perceived as very important to the buyers decision making process and these are "Searching" and "Technical Support".

It was probably not surprising that the sub-functions of "On-Time Delivery", "Product Availability”, "Credit Payment" and "Technical Support" were also viewed so importantly by the buyers. To provide these sub-functions requires local ground support and these are not the services that can be provided by e-B2B exchanges alone without alliances with any local intermediaries. The sub-functions of "Aggregating" and "Searching" were also perceived as very important to the buyers and the buyers can look to the e-B2B exchanges and to the TI to provide these services as both are capable of supply it. If buyers are looking for the TI to supply these services this could indicate that perhaps e-B2B exchanges may not be as efficient as claimed to be and buyers were not able to get satisfactory services from the e-B2B exchanges. So buyers instead look to the TI to play these roles.

The impact on the chemical industry was that whilst the e-B2B exchanges have a role to play in the chemical supply chain management there were still subfunctions which the buyers viewed that the TI could offer to them. So the supplierbuyer relationships could be maintained between the buyers and the TI, at least for the time being, until newer business models of e-B2B exchanges begins to compete with the TI's to offer these sub-functions.

From the consumers' perspective it was not surprising that the chemical buyers surveyed viewed the market sub-functions of "On-time Delivery", "Product Availablility”, “Trust Partner, “Agreggating” and "Credit Payment” as very important. All the end-users wanted are that products are available as and as when they needed it and that the products are of the quality that they have contracted to buy. This is consistent with the concept of channel strategy proposed by Pitt \& Watson (1999) where customers want the right quantities of product or service available at the right place and at the right time. The end-users would want to buy products from companies whom they felt are trustworthy so that they are confident that the right quality products are delivered on the date that was agreed upon. It is equally important that the products are being supplied by trustworthy partners so that in case of any product quality issues the buyers know that they can hold someone responsible for it. This is in-line with what Zucker (1986) proposed for his processbased trust production that trust are built up through repetitive transactions and are related to the past or expected exchanges such as reputation or accumulated experiences. The more the customer trusts the distributor the higher will be the perceived value of relationship. Osterwalder \& Pigneur (2002) stated that "Trust" has become one of the most important elements in a business world. Czinkota \& Kotabe (2000) too viewed that distributors' value cannot be realized without the presence of 
trust and that trust and communication are interrelated aspects. According to Doney \& Cannon (1997) trust is perceived credibility and it enable buyers and suppliers to focus on long term relationships (Ganesan 1994) and they are the commitment to business relationship (Morgan \& Hunt 1994).

If buyers can buy on credit terms they are then able to make payments for the products they bought only some period after they have used it thus improving their internal cash flows. As end-users of the chemical products they would be very knowledgeable on the usage of the products and would also be fully aware of the legality and regulatory requirements of it. So whether the chemical distributors know about the legal and regulatory requirements of the products would be of secondary importance to the chemical buyers since they know about it and are not dependant on the chemical distributors for advice in these matters. Mudambi and Aggrawal (2003) postulated that buyers wants to work with distributors to increased stability of supply, improve discounts due to economies of scale, reduce their working capital and inventory through the provision of credit and financing. Buyers treats vendor's technical expertise as a strategic resources and added value (Ghingold \& Johnson 1997) and buyers value the ability of distributors to offer cutting edge technical assistance which are the important competitive advantage for distributors. Buyers are looking towards distributors to provide specialised process knowledge, specific knowledge of the business and good market knowledge (Mudambi \& Aggarwal 2003).

The chemical buyers viewed the market sub-function of "Blending/Repackaging” as not at all important could be that the respondents may not be from the manufacturing department and so possibly may not be fully aware of the convenience of using the products from distributors that are being blended specially for them. It is also likely that the chemical buyers viewed that this is part of their internal specialty knowledge and they do not require any outsider to blend or repack products for them. It is highly likely that some of the chemical buyers responding to the survey may not be from full fledged manufacturers and that they are actually blenders or repackers themselves. In such cases it would be logical for the respondents from the buyers' category to reply that this sub-function is not important to them at all to be offered by chemical distributors.

Of the thirteen market sub-functions surveyed the chemical distributors viewed that eleven of them are very important to them. The researchers' surmized that the chemical distributors are probably "over-glorifying" their roles as distributors and that the chemical distributors felt that everything they do is important to them and so it should be important to others as well. This may or may not be true from the buyers' perspectives but however both of them seem to be in agreement on the importance of a number of the market sub-functions. Distributors are able to share their technical product knowledge with customers on the physical capabilities of of the products and relative advantage of one over the other (Mudambi \& Aggarwal 2003). The distributors can offer technical process knowledge and they understood how the customers actually use the products and the factors affecting product usage in the field (Pfeffer \& Sutton 1999). The market knowledge that the distributors possessed also adds value to customers and in addition the distributors possessed good information sources on current and future demands and how best to satisfy the customers' demand. Distributors are able to add value to customers by managing the logistics and transportation involved in the physical movements of the products which 
includes monitoring of shipping and delivery services (Mudambi \& Aggarwal 2003). Distributors too effectively can reduce the working capital of customers through efficient inventory management, reducing leadtime, offering trade credit and financing activities. These roles are in convergence to what the buyers also demanded from the distributors as borne out from this research.

The chemical distributors rated the market sub-function of "Regulatory" as only somewhat important and "Blending/Repackaging" is not important at all to them. So it is not altogether true that the chemical distributors are not discerning enough on the different market sub-functions as they single these two markets sub-functions out as somewhat to not important all. The reasonings for these are not altogether apparent and it could probably be that some of the chemical distributors surveyed were not capable of offering the service of "Blending/Repackaging" and thus viewed them as not important at all since they are not offering it. As for "Regulatory" matters it is puzzling that the chemical distributors viewed them as only somewhat important because one would have thought that this is an important sub-function since the handling of chemicals are regulated by local legislations. So knowledge of the "Regulatory" matters would certainly be viewed as not only important but also as essential to the services that they are offering.

Whilst this research is on the disintermediation of traditional chemical intermediaries roles by electronic B2B marketplace it would be interesting to make a brief comparison on what is happening to other industries in the face of competition from e-b2b marketplace. Are there any industries facing extinction or industries been badly disintermdiated and changed in the way they operate due to the adoption of e-B2B marketplace? Knowledge of this could be useful ground for further research into the mechamism of disintermediation for the different industries by e-B2B marketplace and whether any lessons can be learnt which could apply to the chemical distribution trade. A brief review of three other industries is undertaken here i.e. the airlines travel, apparel and the books industries. This will present a combination of industries that does not require physical deliveries and inspection of good (Clemons \& Aron 2002) (i.e. airlines travel ticketing industry), industry that requires physical deliveries and inspection of goods (i.e. apparel industry) and industry which has a combination of both requiring physical deliveries of goods (i.e. books retailing industry) as well as non physical delivery of goods (i.e. e-books industry)

Clemons and Aron (2002) suggested that two categories of products i.e. one that needs physical inspection and the other one that do not need physical inspection. For products that requires physical inspection are because consumers want to assure themselves that the products met with their desired quality levels, their desired sets of attributes incuding workmanship and appearance and that the products fits them. Products that do not need physical inspection are ideal for adoption of online trading and the online airline ticketing activity are ideal for the adoption of online strategy.

For the airline industry traditionally travelers wishing to purchase airline tickets either go to the airline ticketing office or to their travel agents. Airlines have used intermediaries and different distribution channels for selling their flight tickets. For this service the airlines pay the travel agents a commission on the issuance of the ticket. The flight ticketing for the travel industry is well suited for e-commerce as there are increasingly more and more companies purchasing their flight tickets 
directly from airlines without going through any intermediaries (Holma N.D.). The business model of the low cost budget airlines were set up with the concept of retailing their flight tickets online without using any intermediary to save cost. So travel agencies have to adopt new strategy and called themselves travel management companies to signal the changes that they are now no more just ticketing agents but also providing other value added services like providing information management and developing customer-supplier relationships (Holma N.D.).

Figure 5 shows the relationship between the airlines companies, travel agents and the clients.

Figure 5: The changing roles in the Triadic Relationship in Business Travel

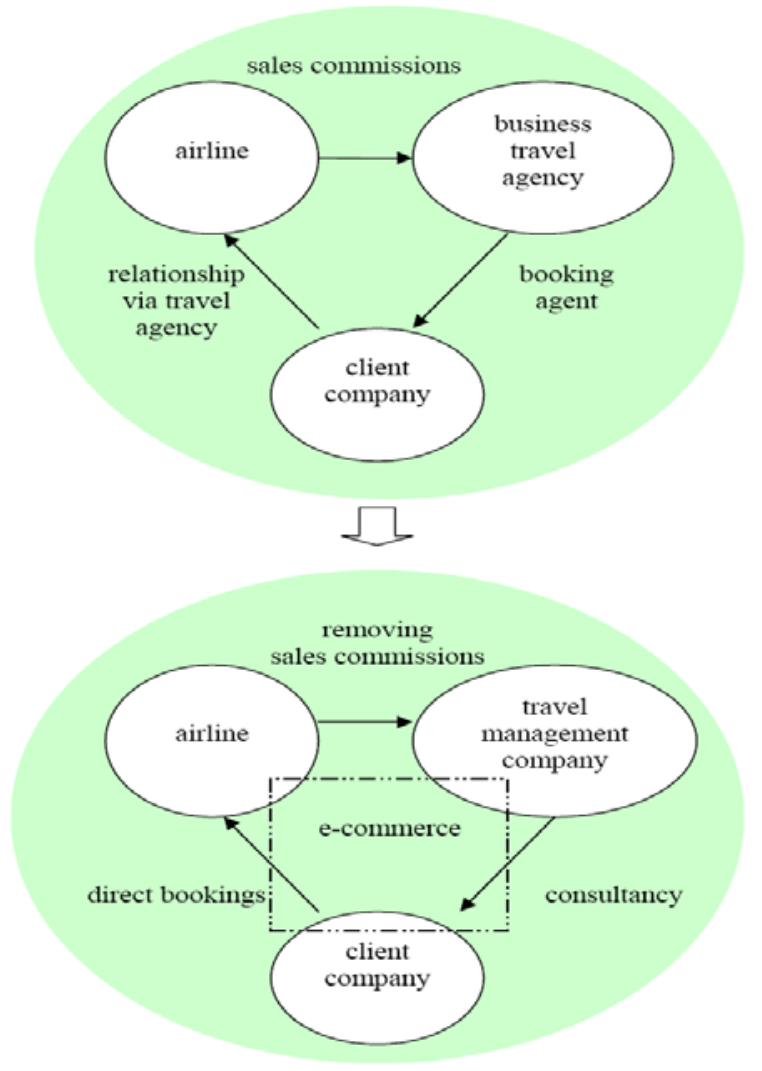

Source: Holma N.D.

It is clear that online activity has caused disintermediation of the travel agents as the customers are constantly pushing for lower transaction costs to reduce travelling expenditures. With internet technology this is now possible. This has caused the travel agents to change their scope of work to continue to survive in the industry and in the process caling themselves as travel consultants.

Figure 6 shows the airlines distribution channels. Airlines used a system called the “Global Distribution Systems (GDS)” which offers computerized ticket distribution through the internet thus enabling direct access by consumers. 


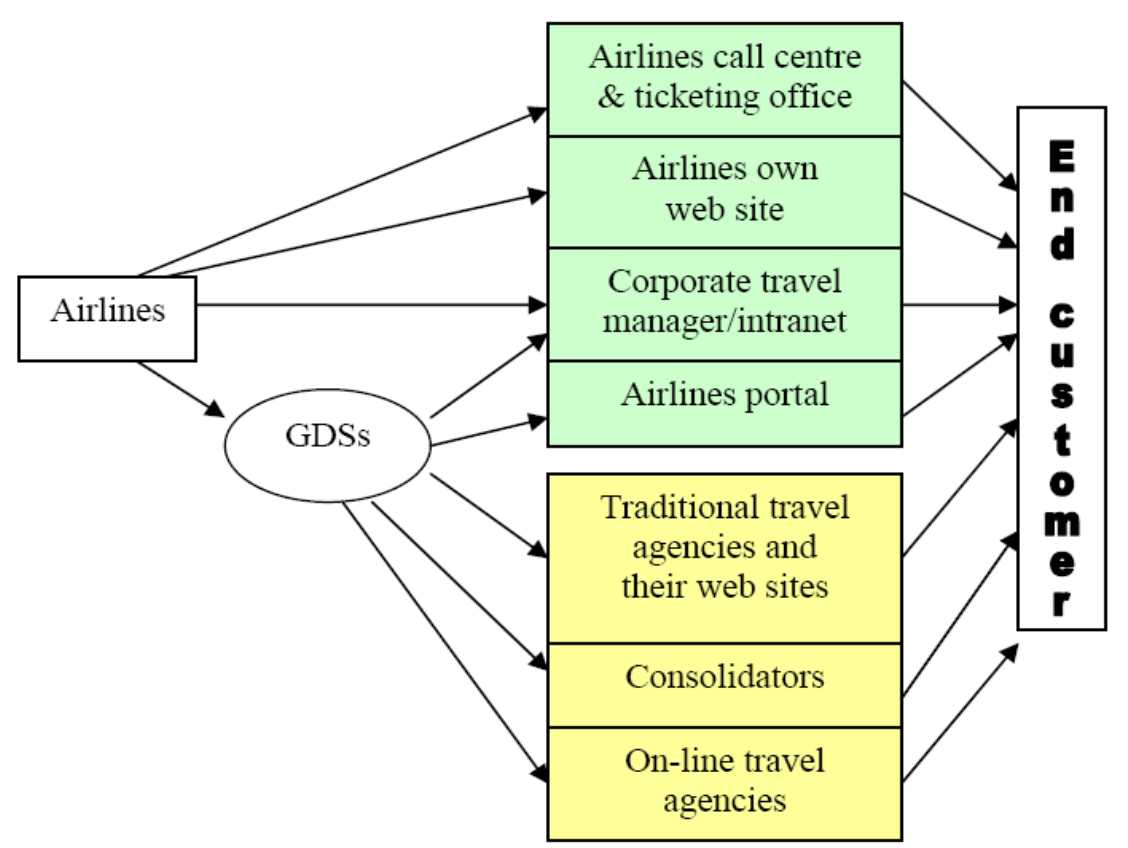

Source: Alamdari 2002, p. 340 (cited in Holma N.D.)

Travel agents too have access to the same system and so travel agents can reintermediate themselves by adopting this technology and offering customers some additional value added services (Bedard 2002 \& Alamdari 2002, cited in Holma N.D.). With the introduction of GDS disintermediation can be from two fronts. Customers can now buy directly from the airlines via their own proprietary website, portals and airline ticketing offices without going through any intermediary (Bedard 2002, cited by Holma N.D.). In addition customer can also just book directly through the internet system.

Consumers will spend US\$19.3 billion on apparel, accessories and shoes in 2008 and this will rise to US\$28 billion by 2011 as reported by Lamm (2008). For the apparel retailing industry physical retail stores in the high streets provided consumers with the sensory stimuli of touch, feel and even smell (Rao 1997). It provided customers with many important data points before decisions are made and visiting the shops is an experience itself. Consumers can interact with in-store personnel and they can try out the product right at the store. Physical retailing store offers instant gratification to the customers (Rao 1997). Given this scenario one would have thought that online retailing would not cause any issues to the traditional retailers. This perception has proven to be wrong. Many retailers are abandoning single business model to go for multi-chnannel strategies linking their e-commerce, catalogs and call centers and store operations (Haydock 2000). Internet store offered a parallel channel to traditional outlets and catalogues for customers to choose from (Tuunainen \& Rossi 2002). They used cross channel advertising and promotion in all media to drive traffic to their desired channels. They are in fact combining clicks and mortar stores with online sales with physical retail outlets. Figure 7 shows an example of a multi channel distribution system which is applicable to the apparel industry. 


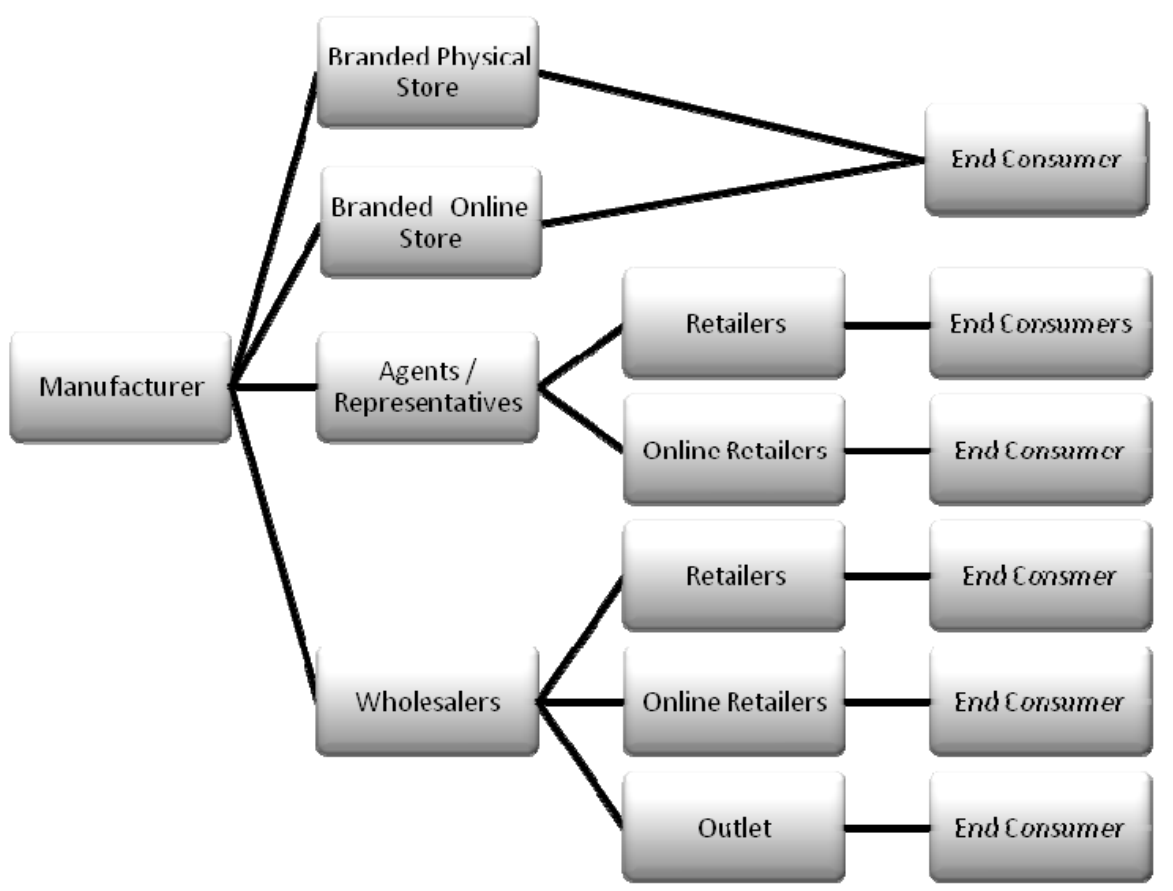

Source: Stenvall 2010, p.10

Figure 7 showed that manufacturers used a combination of the physical retail shops and online retailers to market their products. Tsay (2004) potrayed a scenario of channel conflict between established conventional stores and newly created online channel. To overcome this channel conflict, or at least to minimize it, Tsay (2004) suggested the manufacturers to change their wholesale prices, provides commission for stores or conceeding demand fulfillment entirely to stores. Stenvall (2010) proposed four approaches that can minimize channel conflict and they are product selection, pricing, promotion and communication. This is similar to what was suggested by Tsay (2004) as described earlier.

Even with the possibility of creating channel conflict this has not stopped apparel manufacturers to sell their goods online. Levis Strauss experimented with online retailing but later on withdrawn it as it was not successful but instead they turned to using the website as a way to shape and market their brands. Levi Strauss discontinued online jean sales on its web after distributors and retailers complained and now they sells through retail sites that carry Levi's brand. In 2000 Mattel sold kids apparel over its Barbie.com website and as a result retailers complained about it saying that the site and catalog posed competitive situation with them even though Mattel prices were 15\% higher than in retail stores and hot seeling items were not on sale on their website (Webb 2002). Mattel and Levis Strauss are using multi-level retail channels selling their mass customized products efficiently via the internet and they are in direct interaction with their consumers. Direct sales channels also provided an avenue for manufacturers to push through visions and create new innovative ways to meet increasing demand and changing market conditions (Van Goor 2001). 
Since then many many large apparel retailers like Gaps and J C Penney have taken a multi-faceted approaches developing sales and marketing sites linking emails, shopping portals and retails shops through internet (Hill 2000). JC Penney, USA which is the largest catalogue sellers, applies a multichannel approach in their sales and services network. Customers can have a choice of visiting one of the 1,100 stores, order from one of JC Penney's numerous catalosgues by phone or from website or shop at JC Penney internet store (Tuunainen \& Rossi 2002).

Patterson (2009) did a case study on Nordstrom (www.nordstrom.com) which is a major apparel retailer in the United States. Retailers like Nordstrom were creating a "Store-within-a-store" concept. Whilst having their physical retailing stores they also set up online capability where manufacturers can advertise their products directly. So manufacturers are able to maintain a control on their branding images and the online marketing content as well as gaining online sales without incurring additional cost to set up the online infrastructure themselves (Patterson 2009). This worked well for the smaller apparel manufacturers. Nordstrom called this "Store-within-a-store" concept their "Brand Boutiques" and it provided a model of cooperation between retailers and manufacturers (IBM 2002, cited in Patterson 2009). The online materials are controlled by the manufacturers but the transactions occur through Nordstrom's online platform. Nordstrom have an effective return policy for goods purchased through the online system. Goods return is an important aspect of e-commerce customer service (Epstein 2004). Customers can return goods which they bought online if they are not satisfied for whatever reasons through the mail or through the stores without much fuss at all. So the apparel industry would appear to have found a way to co-exist with their manufacturers by embarking on multi-channel distribution concept, at least for now.

For the book retailing industry two companies are highlighted here and they are Barnes \& Noble (www.bn.com) and Amazon.com (www.amazon.com). The two companies were chosen to show the diversities of the two companies' business model, with Barnes \& Noble which started as a "Brick-and-Mortar" bookstore and later on migrated to the e-commerce platform to sell their books to complement their physical bookstores and Amazon.com which started life as an on-ine bookstore.

Barnes \& Noble is an example of a traditional intermediary where they stocks and sells books in their bookstores. They have been a prominent book retailer for about 40 over years and today it has 1,362 stores, including 719 superstores (Tractenberger 2010 \& www.bn.com). The digital revolution was sweeping the media world and is causing competition with established businesses like Barnes \& Noble. With the fast accelerating adoption of e-books it forces book retailers, publishers, authors and agents to reconsider their business model. So Barnes \& Noble which has been amassing more than 150,000 books over the past decades under one roof was under pressure from online booksellers. Barnes \& Noble was one of the first to embrace digital book business when in 1998 it made a small investment in NuvoMedia Inc., maker of a handheld device called the Rocket eBook reader (Tractenberger 2010). In what was later proved to be their largest strategic blunder, Barnes \& Noble killed the venture in 2003. At that time e-book were selling for about \$20 or more and \$25 for hardcover and it was not attractive for consumers to switch to e-books. 
Today Barnes \& Noble laid claim to be the world largest eBook store with over 2 million eBooks. It has the advantage of vast warehouses across the United States which stock over 1 million titles for immediate delivery. Barnes \& Noble can leverages on the power of the Barnes \& Noble brand to offer online customers the Web's premier destination for books, eBooks, magazines, toys \& games, music, DVD and Blu-ray, video games, and related products and services (www.bn.com).

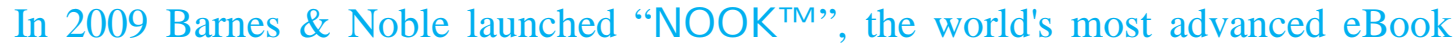
reader that features groundbreaking technology, a color touchscreen and lets readers download books in seconds.

E-books don't require paper, printing presses, storage space or delivery trucks and they typically sell for less than half the price of a hardcover book. So Barnes \& Noble strategy to embark on to selling e-books was a matter of survival otherwise their business will be cannabalized by other e-Book sellers like Amazon.com. However if physical book sales decline too greatly then book retailers with physical stores will not be earning enough to support their stores (Tractenberger 2010). Operating physical stores are very expensive with huge fixed costs like rental, estate maintenance and staff salaries to mind the shops. This is the dilemma facing Barnes \& Noble right now. The future of Barnes \& Noble's bookstores may boil down to whether consumers prefer digital books as much as they preferred digital music and if that is the case then physical stores may possibly all disappear.

Amazon's corporate vision is that “we seek to be earth's most customer-centric company for three primary customer sets: consumer customers, seller customers and developer customers" (www.amazon.com). Amazon started business in 1995 by focusing on massive selection, service quality, simplicity, efficiency and pricing for the selling of books online. The attractiveness of the business model was that there was no expensive real estate to inventory the books and they can offer a very wide range of books for consumers competitively (Mendelson \& Meza 2001). Another advantage of Amazon business model was the speed at which they collect the cash. Once the customer purchased the books the company received the cash very soon after that and Amazon did not need to pay the publishers for the inventory until about 60 days later. So Amazon had the use of the funds for the best part of a month without paying any interest

Amazon is a virtual retailer and they proudly claimed that they carry the minimum of inventory and relied on rapid fulfillment from major distributors and wholesalers. The electronically ordered books are being shipped to customers within hours of receiving the shipping orders from Amazon (Mendelson \& Meza 2001). Initially for selling of books the outsourced fulfillment by third party distributors was adequate but however as Amazon addded on more items to its range of products this was very soon not adequate for its purpose. So in 1999 Amazon expanded its infrastucture and started to build its own distribution centre. This of course required a lot of capital investments by Amazon to build the distribution network which adversely affected their financial performance.

However in 2001 Amazon reversed their strategy and use distributors to drop shipments to their customers again. Amazon used a combination of their facilities as well as their distributors to re-packed books. In April 2001 Borders, another book retailer, decided to close its own online channel distribution and partnered it with 
Amazon. In November 2007 Amazon launched the "Kindle" e-reader which was a success and proved to the publishers that the e-books market was real. In the third quarter of 2010 Amazon registered net sales of US\$7.56 billion as compared to sales of US\$5.45 billion in the same period of 2009 (http://phx.corporate-ir.net). For the same period Amazon made a net income of US\$231 million as compared to US\$199 million for the same period in 2009. So e-book retailing can be profitable, at least for Amazon now after many years of under-performing financially.

So the fortunes of both these companies are very different. Barnes \& Noble are struggling to find a strategy to succesfully combining their online e-books sales in combinations with their bookstores retailing business. Meanwhile Amazon seems to have found a succesful combination of e-book selling whilst having a mixed distribution channels for the physical deliveries of books.

So in summary it can be observed that disintermediation through e-B2B marketplaces has taken place in various degree in mnay of of the industries. From the three examples taken above it can be observed that the airline ticketing industry has been badly affected by the online ticketing system and thus causing major industry reorganization with travel agents renaming themselves as travel consultants offering many more value added services. The book retailing industry too has shown different economic viability of e-Books selling as against physical bookstores retailing with the physical bookstores losing grips in the industry. The apparel industry has gone for multi-channel marketing embracing the virtues of onlin retailing as well as having physical retail stores offering consumers the personal touch and feeling of the goods.

Alamdari, F 200, 'Regional Development in Airlines and Travel Agents Relationships', The Journal of Air Transport Management, Vol 8, pp.339-348;

Amazon.com background information, viewed 16 November 2010,

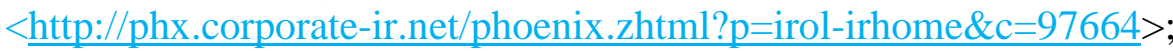

Bedard, F 2002, 'Travel Agencies in the Era of E-Commerce', Marketing Papers, World Tourism Organization, Madrid, pp.67-86;

Borenstein, S \& Saloner, G 2001, 'Economics and Electronic Commerce', The Journal of Economic Perspectives, vol. 15, issue 1, pp.3-12;

Clemons, E K \& Aron, R 2002, 'Online Distribution: A Taxonomy of Channel Structures, Determinants of Outcome, and Determinants of Strategy, Proceedings of the $35^{\text {th }}$ Hawaii Conference on System Sciences;

Czinkota, M R \& Kotabe M, 2000, 'Entering the Japanese Market: a Reassessment of Foreign Firms’s Entry and Distribution Strategies, Ind. Mark Manage, Nov., vol. 29, pp. 483-491;

Doney, P M \& Canon, J P 1997, 'An Examination of the Nature of Trust in buyerseller Relationship’, J Marks, April, vol 61, pp. 35-51; 
Epstein, M 2004, 'Implementing E-commerce Strategies: a Guide to Corporate Success after the Dot.com Bust', Westport, Praeger Publishers;

Ganesan, S 1994, 'Determinants of Long-Term Rrelationship in Buyer-Seller

Relationship’, J Marks, April, vol. 58, pp. 1-19;

Haydock, M 2000, 'Multichannel Strategies Win Confidence’, DM news, 21 Aug. p. 32 ;

Hill, S 2000, 'To De-Mall or Email?: Shaping Web Shopping', Apparel Industry Magazine, pp. 36-38;

Holma, A N.D., 'Triadic Business Relationships: The Changing Role of Intermediaries in the Business Travel', Swedish Schoool of Economics and Business Administration, Department of Marketing;

IBM Corporation 2002, 'Apparel Manufacturing Industry Brief, <www.200.ibm.com/partnerworld/pwhomes.nsf/vassetslookup/apparel>;

Kumar, K 2001, 'Technology for Supporting Supply’, Commmuincations of the ACM, vol. 44, no. 6, viewed on 16 November 2010 on ebscohost, $<$ http://web.ebscohost.com.proxy.library.adelaide.edu.au>;

Lamm, G 2008, ‘Nordstom's Online Sales Surging', Pudget Sounds Buisness Journal, Aug, <www.bizjournal.com/stories/2008/252.html>;

Morgan, R M \& Hunt, S D, 1994, 'The Commitment-Trust Theory of Relationship Marketing’, J Marks, July, Vol. 58, pp.20-38;

Mudambi, S \& Aggarwal, R 2003, 'Industrial Distributors: Can They Survive in the New Economy’, Industrial Marketing Management, vol. 32, pp.317-325;

Nordstrom corporate website, viewed on $18^{\text {th }}$ November 2010, $<$ http//www. Nordstrom.com>;

Osterwalder, A \& Pigneur, Y 2002, 'An e-Business Model Ontology for Modeling eBusiness, e-Reality: Constructing the E-Economy’, $15^{\text {th }}$ Bled Electronic Commerce Conference, Slovenia;

Patterson, M 2009, 'The Impact of E-commerce on Traditional Retailers Case Study: Nordstrom’, Ball State University Muncie Indiana, May, degree thesis;

Pfeffer, J \& Sutton, R I 1999, 'Knowing What To Do Is Not Enough: Turning Knowledge Into Action', California Manage Review, vol 42 issue 1, pp.83-108;

Pitt, L \& Watson, R T 1999, 'Changing Channels: The impact of the Internet on Distribution Strategy’, Business Horizons, Vol. 42, issue 1, pp. 19-28;

Rao, B 1997, 'The Internet and the Revolution in Distribution: A Cross-Industry Examination', Technology in Society, Vol. 21, pp. 287-306; 
Schoenbachler, D D \& Gordon, G L 2002, 'Multi-Channel Shopping: Understanding What Drives Channel Choice', The journal of Consumer Marketing, vol. 19, issue 1, pp. 42-53;

Stenvall, C 2010, 'Internet Retailing: The Future of Branded Apparel Companies, Intentional and Unintentional Approaches that can Minimize Channel Conflict, Arcada, Degree Thesis;

Trachtenberg, J A 2010, 'E-Books Rewrite Bookselling’, Wall Street Journal, May 21, viewed on 17 November 2010,

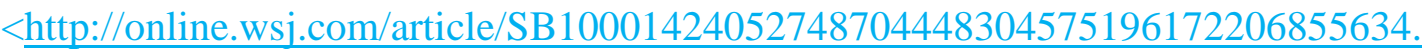
$\underline{\mathrm{html}>}$

Tsay, A A \& Agrawal, N 2004, 'Channel Conflict and Coordination in the ECommerce Age, Production and Operations Management, vol. 13, pp.93-110;

Tuunainen, V K \& Rossi, M 2002, 'E-Business in Apparel Retailing Industry-Critical Issues’, ECIS June 6-8, Gdansk Poland, Helsinki School of Economics;

Van Goor, Ad R 2001, 'Demand \& Supply Chain Management: A Logistical Challenge', $17^{\text {th }}$ International Logistics Congress, Thessanlonki;

Webb, K L 2002, 'Managing Channels of Distribution in the Age of Electronic Commerce’, Industrial Marketing Management, vol. 31, pp.95-102;

Zucker, L G 1986, 'Production of Trust: Institutional Sources of Economic Structure 1840-1920’, Research in Organziation Behavior, vol. 8, pp.53-111;

\section{Conclusion}

The research shows evidence that buyers were currently buying from e-B2B exchanges. There were consensus from both the distributors and buyers on the roles that needed to be provided to the buyers by distributors to ensure the continuing relationships between them. So the buyers see a role for the TI in their supply chain and the TI will possibly not face total disintermediation by e-B2B exchanges. However from evidence gathered in this small preliminary survey the TI's have to share the business with e-B2B exchanges and they are possibly facing a partial disintermediation from e-B2B exchanges.

The summary of the findings relevant to the research questions and objectives for this research are as follows:

1. Each of the types of e-B2B exchanges, i.e. independent, private and consortiumled, appear to be able to cause partial disintermediation of the roles of the TI;

2. In the one sample t-tests, the buyers viewed the sub-functions of "On-Time Delivery”, "Product Availability”, “Aggregating” and "Credit Payment” as being very important to them. The distributors also viewed all the sub-functions as very important to them except for the sub-functions of "Blending/Repackaging" and "Regulatory". Both the distributors and buyers viewed the sub-function of "Blending/Repackaging" as not at all important to them; 
3. From the independent two samples t-tests results, it was observed that there were significant differences in the preferences between the buyers and distributors for the sub-functions of "Determination of Product Offerings", "Searching", "Price Discovery”, "Product Availability”, “On-Time Delivery”, "Product Knowledge” and "Legal"; and

4. From the Spearman Correlation Coefficient obtained for the ranks data, it was observed that the distributors and buyers have very high agreement on the overall order of preferences of the sub-functions.

\section{Limitations and Future Research}

In this research a cross-sectional approach of data collection was adopted instead of a longitudinal method. Longitudinal data collection may have been a better approach to track the trends of the adoption of EC by chemical buyers and also their preferences towards using e-B2B exchanges to make purchases instead of using TI's. However due to the limitations of time and financial resources the cross-sectional data collection method was used in this research. A limitation was also encountered when performing the content analysis of e-B2B exchanges especially for the private type eB2B exchanges. All of them are password protected and so it was not possible to check out the transaction facilities in detail. Thus the content analysis was conducted by relying on the description in the exchange itself and not through testing the facilities.

The limitations in this research provided a multitude of topics for future research in the field of disintermediation of the TI in the chemical industry due to e$\mathrm{B} 2 \mathrm{~B}$ exchanges. The following are some of the suggested topics that may be of interest for future research:

1. A longitudinal study of chemical e-B2B exchanges development and determination of the extent of disintermediation of traditional chemical distributors over the period;

2. Case study of e-B2B exchanges and the quantitative disintermediation damages caused to the traditional chemical distributors; and

3. Investigation of the development of e-Distributors in the chemical industry and to evaluate whether this is the new business model for chemical distributors for reintermediation. 


\section{REFERENCES}

Bailey, J P \& Bakos, Y 1997, 'An Exploratory Study of the Merging Role of Electronic Intermediaries', International Journal of Electronic Commerce, vol. 1, no. 3, spring, pp. 7-20.

Baker, C 2008, 'Survey Methods in Researching Language and Education' in King, K A \& Hornberger, N H (eds), Encyclopedia of Language and Education, $2^{\text {nd }}$ edn, Vol. 10, Research Methods in Language and Education pp. 55-68, viewed 31 January 2008, Springer Newcastle University.

Bakos, J Y 1991, ‘A Strategic Analysis of Electronic Marketplaces’, MIS Quarterly, vol. 15, no. 4, pp. 295-310.

Bakos, J Y 1997, 'Reducing Buyer Search Costs: Implications for Electronic Marketplaces', Management Science, December, pp. 1676-1692.

Bakos, J Y 1998, 'The Emerging Role of Electronic Marketplaces on the Internet', Communications of the ACM, August, vol. 41, no. 8, pp. 35-42.

Balabanis, G 2005, 'Determinants of Export Intermediaries' Service-Mix Configurations’, International marketing Review, vol. 22, no. 4, pp. 436-459, viewed 03 January 2007, ABI/INFORM.

Berg, B 2001, Qualitative Research Methods for the Social Sciences, $4^{\text {th }}$ edn, Needham Heights, M.A., Allyn \& Bacon.

Brenntag Americas Corporate Website, viewed 14 March 2008, $<$ http://www.brenntagnorthamericas.com>

British Chemical Distributor and Trade Association (BCDTA), viewed 09 November 2007, <http://www.chemical.org.uk>

Brousseau, E 1999, 'The Governance of Transaction by Commercial Intermediaries: An analysis of the Re-engineering of Intermediation by Electronic Commerce', $3^{\text {rd }}$ Conference of the International Society for New Institutional Economics, September, Washington DC, USA.I

Bull, 2010, 'Customer Relationship Management (CRM) systems, intermediation and disintermediation: The case of INSG, International Journal of Information Management, vol. 30, no.1, p94-97.

Cap Gemini Ernst \& Young and the University of Tennessee 2000, 'Logistic @internet speed: The impact of e-commerce on logistic Year 2000, report on trends and issues in logistic and Transportation'.

Canadian Association of Chemical Distributors, viewed 09 March 2008, $<$ http://www.cacd.ca $>$

Cartlidge, S 2004, 'The Next Dimension in Chemical Distribution', European Coatings Journal, May, pp.14-16. 
Cavana, R Y, Delahaye, B L \& Sekaran, U 2001, Applied Business Research: Qualitative and Quantitative methods, John Wiley \& Sons Australia.

Chemconnect Corporate Website, viewed 13 March 2008, $<$ http://www.chemconnect.com>

Chircu, A M \& Kauffman, R J 1999, 'Strategies for Internet Middlemen in the Intermediation/Disintermediation/Reintermediation Cycle', International Journal of Electronic Commerce and Business Medias, May, vol. 9, no. 2, pp. 109-117.

Chircu, A M \& Kauffman, R J 2000, 'Reintermediation Strategies in Business-toBusiness Electronic Commerce', International Journal of Electronic Commerce, Summer, Vol. 4 no. 4, pp. 7-42.

Christiaanse, E, Sinnecker, R \& Mossinkoff, M 2001, 'The Impact of B2B Exchanges on Brick and Mortar Intermediaries: The Elemica Case', 9th European Conference on Information Systems, Bled, Slovenia, June 27-29, pp. 422 - 432.

Chung, F L 2001, 'An Analysis of Taiwan's Distribution System', International Journal of Retail \& Distribution Management, vol. 29, no. 2, pp. 87-98, viewed 03 January 2007, Emeraldinsight Newcastle University.

Creswell, J W 2003, Research Design: Qualitative, Quantitative and Mixed Methods Approaches, $2^{\text {nd }}$ edn, Sage Publication, CA, USA.

Datta, P 2005, 'Intermediaries as Value Moderators in Electronic Marketplaces', European Conference on Information System, viewed 01 July 2007, $<$ http://www.csrc.lse.ac.uk/asp/aspecis/20050047.pdf>

Day, G S \& Bens, K J 2005, 'Capitalizing on the Internet Opportunity', Journal of

Business \& Industrial Marketing, vol. 20 no. 4/5, pp.160-168, viewed 01 July 2007, Emeraldinsight Newcastle University.

Dillman, D A 2000, Mail and Internet Surveys: The Tailored Design Method, John Wiley \& Sons, New York

e-Business W@tch 2004, 'The Role of Electronic Business in the Chemical Industries in 2004: Main Issues and Challenges', August, viewed 02 October 2007, $<$ http://www.ebusiness-watch.org>

Elemica Corporate Website, viewed 14 February 2008, <http://www.elemica.com>

European Association of Chemical Distributor, viewed 24 Feb. 2008, $<\mathrm{http}: / /$ www.fecc.org $>$

Evans, J R \& Mathur, A 2005, 'The Value of Online Surveys', Internet Research, vol. 15, issue 2, pp. 195-219. 
Fingar, P, Kumar, H \& Sharma, T 2000, Enterprise E-Commerce: The Software Component Breakthrough for Business-to-Business Commerce, Meghan-Kiffer Press Tampa, Florida.

Formisano, R 2004, Manager Guide to Strategy, McGraw-Hill, USA.

Fung, K O, Chen, S N \& Yip S C 2007, 'Relationships and Performance of Trade Intermediaries: An Exploratory Study’, European Journal of Marketing, vol. 41, no. 1 /2, viewed 12 January 2007, Emeraldinsight Newcastle University.

Giaglis, G M, Klein, S \& O’Keefe, R M 2002, 'The Role of Intermediaries in Electronic Marketplaces: Developing a Contingency Model', Information System Journal, vol. 12, pp. 231-246, viewed 05 August 2006, Blackwell Science.

Ghose, S \& Dou, W Y 1998, 'Interactive Functions and their Impacts on the Appeal of Internet Presence Sites', Journal of Advertising Research, Vol. 38, No. 2, pp. 29-43.

Gilliland, A \& McKemmish, S 2004, 'Building an Infrastructure for Archival Research', Archival Science, Vol. 4, pp. 149-197, viewed 31 January 2008, Springerlink Newcastle University.

Griffis, S E, Goldsby, T J \& Cooper, M 2003, 'Web-Based and Mail Survey: A Comparison of Response Rate, Data and Cost', Journal of Business Logistics, Vol. 24, issue 2, pp. 237-258.

Hair, J F, Babin, B, Money, A H \& Samouel, P 2003b, Essentials of Business Research Methods, John Wiley \& Son, USA.

Hair, J F, Bush, R P \& Ortinau, D J 2003a, Marketing Research: Within a Changing Information Environment, $2^{\text {nd }}$ edn, McGraw-Hill Irwin, New York.

Hammer M 2000, 'The Myth of Disintermediation', Information Week, viewed 20 July 2007, <http://www.informationweek.com/794/94uwmh.htm>

Hoffman, W, Keedy, J \& Roberts, K 2002, 'The Unexpected Return of B2B', McKinsey Quarterly, no. 3.

Huizingh, E K RE 2000, 'The Content and Design of Websites: An Empirical Study', Information \& Management, Vol. 37, no. 3, pp. 123-134.

Journal of Business Logistics, Council of Supply Chain Management of Professionals, viewed 03 May 2008, <http://www.cscmp.org>

Kafka, S J, Temkin, B D, Doyle, B, \& Martin, P 2000, 'The e-Marketplace ShakeOut', The Forrester Report, August, viewed 02 January 2006, $<$ http://www.marketresearch.com/researchindex/275808.html> 
Kaplan, S \& Sawhney, M 2000, 'E-Hubs: The New B2B Marketplaces', Harvard Business Review, May, pp. 97-103, viewed 13 April 2007, Expanded Academic ASAP.

Kirppendorff, K 2004, Content Analysis: An Introduction to its Methodology, Sage Publications, CA, USA.

Lee, Y H, Lee, Z \& Larsen, K R T 2003, 'Coping with Internet Channel Conflict', Communication of the ACM, July, vol. 46, no. 7, pp. 137-142, viewed on 12 February 2006, ebscohost library Newcastle University.

Malone, T W, Yates, J \& Benjamin, R I 1987, 'Electronic Markets and Electronic Hierarchies’, Communications of the ACM, June, vol. 30, no. 6, pp. 484-497.

Malhotra, N K \& Birks, D F 2007, Marketing Research: An Applied Approach, $3^{\text {rd }}$ edn, Prentice Hall, England.

Manfreda, K L, Bosnak, M, Berzelak, J, Haas, I \& Vehovar, V 200, 'Web Surveys Versus Other Survey Modes: A Meta-Analysis Comparing Response Rates', International Journal of Market Research, Vol. 50, Issue 1, pp. 79-104.

McMillann, S J 2000, 'The Microscope and the Moving Target: The Challenge of Applying Content Analysis to the World Wide Web', Journalism and Mass Communication Quarterly, Vol. 77, No.1, pp. 80-98.

McQueen, R A \& Knussen, C 2002, Research Methods for Social Science, Prentice Hall, UK.

Mills, J F \& Camek, V 2004, 'The Risks, Threats and Opportunities of Disintermediation: A Distributor's View', International Journal of Physical Distribution \& Logistic Management, Vol. 34, No. 9.

North American Chemical Distributor Association, viewed 02 Feb. 2008, $<$ http://www.nacd.com>

Overby, J W \& Min, S H 2002, 'International Supply Chain Management in an Internet Environment: a Network-Oriented Approach to Internalization', International Marketing Review, vol. 18, No. 4, pp. 392-420, viewed 02 January 2007, Emeraldinsight Newcastle University.

Parker, L 1992, 'Collecting Data the E-Mail Way', Training and Development, pp. 52-54.

Pavlou, P A \& El Sawy, O A 2002, ‘A Classification Scheme for B2B Exchanges and Implications for Interorganizational eCommerce', Chapter 1, Idea Group Publishing.

Perry, M \& Bodkin, C 2000, 'Content Analysis of Fortune 100 Company Websites', Corporate Communication: An International Journal, Vol. 5, No. 2, pp. 87-96. 
Purchasing Magazine Online 2007, Chemical Market Segments, viewed 25 October 2007, <http://www.purchasing.com>

Research Methods Knowledge Base, The t-Test, viewed 26 July 2008, $<$ http://www.socialresearchmethods.net>

Rosenbloom, B 2007, 'Multi-Channel Strategy in Business-to-Business Markets: Prospects and Problems', Industrial Marketing Management, Vol. 36, no. 1, January, pp. 4-9, viewed 22 February 2007, ScienceDirect Newcastle University.

Ruijter, R D 2004, 'Choosing Business to Business Exchanges in the Chemical Industry: A Model of the Transactional Issues Affecting Choice', August 10, University of Maastricht.

Sarkar, M B, Butler, B \& Steinfield, C 1996, Intermediaries and Cybermediaries: A Continuing Role for Mediating Players in the Electronic Marketplace, Journal of Computer Mediated Communication, Vol. 1, issue 3.

Scandura, T A \& Williams, E A 2000, 'Research Methodology in Management: Current Practices, Trends, and Implications for Future Research', Academy of Management Journal, Vol. 43, No. 6, pp. 1248-1264, viewed 30 January 2008, ABI/Inform Global Newcastle University.

Schaefer, D R, \& Dillman, D A 1998, 'Development of Standard E-Mail Methodology: Results of an Experiment', Public Opinion Quarterly, Vol. 62, issue 3, pp. 378-397.

Schmidt, M J \& Hollensen, S 2006, Marketing Research: An international Approach, Prentice Hall, England.

Sills, S J \& Song, C Y 2002, 'Innovation in Survey Research: An application of Web Surveys’, Social Science Computer Review, Vol. 20, pp. 22-30.

Smith, S 2009, “The Great Disintermediation’, EContent, vol. 32, no.7, p8-8.

Thayer, A 2000, 'E-Business for Chemicals', Chemical \& Engineering news, July 17, Vol. 78, no. 29, pp. 19-26.

Triola, M F 1998, Elementary Statistics, $7^{\text {th }}$ edn, Addison-Wesley, USA.

Tse, A C B 1998, 'Comparing the Response Rates, Response Speed and Response Quality of Two Methods of Sending Questionnaires: Email vs Mail', Journal of the Market Research Society, Vol. 40, issue 4, pp. 353-362.

U.S. Census Bureau E-Stats 2006, E-Commerce Sales for 2004, May 25, viewed on 29 December 2007,

<http://www.census.gov/eos/www/2004/2004reportfinal.pdf>

Yang, S M, Yang, M H \& Wu, J T 2005, 'The Impacts of Establishing Enterprise Information Portals on e-Business Performance', Industrial Management \& Data 
Systems, Vol. 105, No. 3, pp. 349-368, viewed 04 February 2008, Emeraldinsight Newcastle University.

Yin, R K 1994, Case Study Research: Design and Methods, Sage Publications, California, USA

Whinston, A B, Stahl, D O \& Choi, S Y 1997, The Economics of Electronic Commerce, Macmillan, New York.

Wigand, R T 1997, 'Electronic Commerce: Definition, Theory, and Context', The Information Society, vol. 13, pp.1-16. 